Historic, archived document

Do not assume content reflects current scientific knowledge, policies, or practices. 




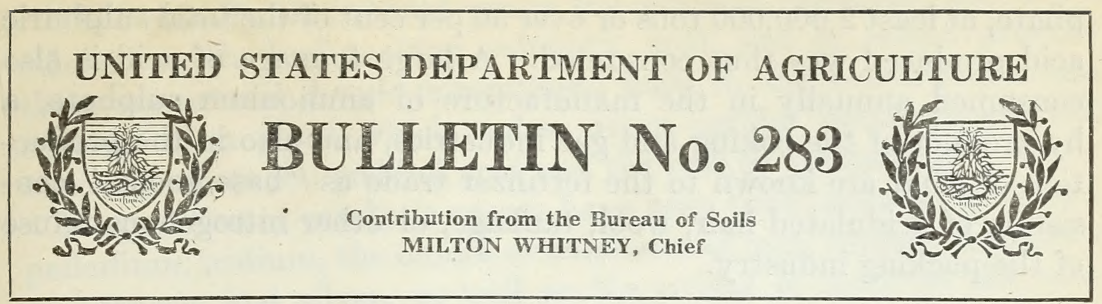

Washington, D. C.

PROFESSIONAL PAPER

September 28, 1915

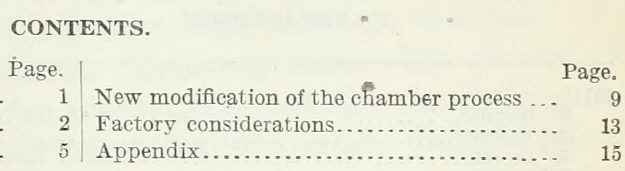

\section{THE PRODUCTION OF SULPHURIC ACID AND A PROPOSED NEW METHOD OF MANUFACTURE.}

By William H. Waggaman, Scientist in Fertilizer Investigations.

\section{INTRODUCTION.}

The importance of sulphuric acid in science, arts, and manufacture has been increasing steadily for many years. Although scarcely any industry exists which does not employ this acid either directly or indirectly in the manufacture of its product, ${ }^{1}$ the bulk of the sulphuric acid produced, both in this country and abroad, is used in the manufacture of fertilizer materials.

- Since Liebig first proposed the treatment of bones or phosphate rock with sulphuric acid in order to render the phosphoric acid present water soluble, superphosphate has been the basis of the fertilizer industry, and the economic production of sulphuric acid has been the aim of numerous investigators and chemical engineers. The production of sulphuric acid of various strengths in the United States for the past three years, according to the figures of the United States Geological Survey, is given in Table I.

Because of the difficulty in shipping such a commodity all of the sulphuric acid produced is consumed in this country. Some of the products manufactured therefrom are shipped abroad but the quantity of acid entering into them is but a small percentage of the total production.

In 1913 the United States consumed 1,931,468 short tons of phosphate rock. Since practically all of this was made into acid phos- 
phate, at least 2,000,000 tons or over 56 per cent of the total sulphuric acid produced was thus consumed. A large tonnage of acid is also consumed annually in the manufacture of ammonium sulphate, a by-product of the coking and gas industries, and also in the production of what are known to the fertilizer trade as "base goods," consisting of acidulated hair, wool, tankage, or other nitrogenous refuse of the packing industry.

TABLE I.-Production of sulphuric acid in the United States for the years 1911, 1912, 1913, by grades.

\begin{tabular}{|c|c|c|c|}
\hline Year and grades. & Quantity. & Value. & $\begin{array}{l}\text { Price per } \\
\text { ton. }\end{array}$ \\
\hline 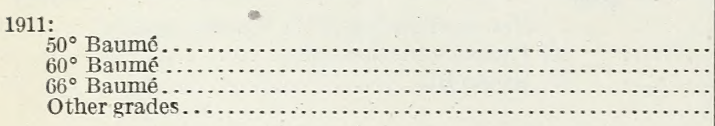 & $\begin{array}{r}\text { Tons. } \\
1,026,896 \\
421,165 \\
751,541 \\
10,728\end{array}$ & $\begin{array}{l}\text { Dollars. } \\
5,447,958 \\
2,624,042 \\
9,176,297 \\
121,575\end{array}$ & $\begin{array}{r}\text { Dollars. } \\
5.31 \\
6.23 \\
12.21 \\
11.33\end{array}$ \\
\hline Total and average ... & $2,210,330$ & $17,369,872$ & 7.86 \\
\hline Total recuced to $50^{\circ}$ Baumé. & $12,688,456$ & $117,313,822$ & 6.44 \\
\hline 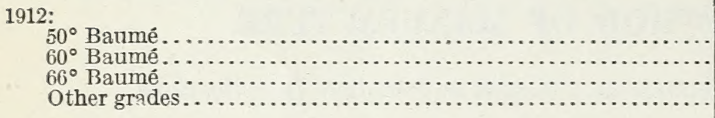 & $\begin{array}{r}1,047,483 \\
451,172 \\
774,772 \\
66,166\end{array}$ & $\begin{array}{l}5,378,411 \\
2,727,764 \\
9,360,630 \\
871,214\end{array}$ & $\begin{array}{r}5.13 \\
6.05 \\
12.08 \\
13.17\end{array}$ \\
\hline Total and average.. & $2,339,593$ & $18,338,019$ & 7.84 \\
\hline Total reduced to $50^{\circ}$ Baumé. & $22,876,000$ & $17,572,837$ & 6.11 \\
\hline 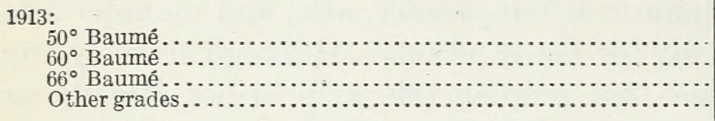 & $\begin{array}{r}1,643,318 \\
509,929 \\
797,104 \\
63,158\end{array}$ & $\begin{array}{l}9,212,917 \\
3,202,528 \\
9,282,422 \\
986,659\end{array}$ & $\begin{array}{r}5.61 \\
6.28 \\
11.65 \\
15.62\end{array}$ \\
\hline Total and average. & $3,013,509$ & $22,684,526$ & 7.53 \\
\hline Total reduced to $50^{\circ}$ Baumé. & ${ }^{3} 3,538,980$ & ${ }^{3} 22,366,482$ & 6.32 \\
\hline
\end{tabular}

1 Exclusive of acids of strength greater than $6 \xi^{\circ}$ Baumé.

2 Exclusive of electrolyte and acids of strength greater than $69^{\circ}$ Baumé.

3 Exclusive of 22,947 short tons of fuming acid, not convertible, valued at $\$ 318,044$.

\section{METHODS OF MANUFACTURE.}

There are two general methods employed in the manufacture of sulphuric acid, namely the "contact process" and the "lead-chamber method." It is not within the scope of this paper to discuss in detail the numerous modifications of these two methods, but classified lists of the patents on the subject, together with short abstracts thereof, are given at the end of this paper.

\section{THE CONTACT PROCESS.}

Briefly the contact process consists in passing a purified mixture of air and sulphur dioxide derived either from sulphur or burning pyrites over some catalytic agent heated to dull redness, thereby effecting the further oxidation of the sulphur dioxide. The resulting sulphur trioxide is then usually absorbed in sulphuric acid, producing a very concentrated product. 
Theoretically this should prove the simplest, cheapest, and most efficient method of making sulphuric acid, but in actual practice there are several details encountered both in the construction and running of a plant which unless given careful consideration will seriously affect the yield of acid and the cost of production.

Many different catalytic agents have been tried (notably platinum, palladium, iridium, the oxides or sulphates of iron, copper, chromium manganese, and silver, as well as the oxides of some of the rarer elements) in effecting the oxidation of sulphur dioxide, but no matter what catalyzer is used its efficiency is seriously impaired and often destroyed unless very elaborate systems are employed for purifying the gases before admitting them into the oxidation chamber. For instance, finely divided platinum (platinum black) has proved the most efficient catalyzer so far discovered, but the catalytic power of this body in bringing about the union of sulphur dioxide and air is seriously affected by the smallest traces of arsenic in the gaseous mixture. When pyrites are used as a source of sulphur dioxide, the arsenic which this mineral nearly always contains, passes over with the furnace gases and it is only by repeated washing and filtering that the last traces of this element can be removed.

Contrary to general opinion, therefore, a contact plant is both elaborate and costly and strict supervision by a competent chemical engineer is necessary to insure the best results.

The contact process has distinct advantages over the lead-chamber method where a pure concentrated acid is required, but in the manufacture of ordinary sulphuric acid $\left(50^{\circ}\right.$ to $60^{\circ} \mathrm{B}$.) for the fertilizer industry or for other purposes where the purity of the product is not essential, the latter method still holds first place (at least in this country) for efficiency and low cost of production.

\section{THE LEAD-CHAMBER PROCESS.}

The lead-chamber process with its various modifications has been fully treated by Lunge. ${ }^{1}$ This author, as well as numerous other investigators, notably Weber, Winkler, Rascheg, Meyer, Pratt, Gilchrist, Falding, and Wedge, has described details of construction; methods of accelerating the chamber reactions, and proposed and discussed schemes for increasing the efficiency and lowering the cost of acid systems. It is thought, however, that a brief general description of the chamber process will help toward a better understanding of the modification of the process proposed in this paper.

In this country nearly all of the sulphuric acid is made from pyrites. The lump ore is imported chiefly from Spain, while the "fines" are a domestic product mined in Virginia, Georgia, Tennessee, and California. If the lump ore is used it is burned in brick 
furnaces having grates composed of single square bars which can be turned on their longitudinal axes to let the cinders down into the ash pits. Such furnaces hold from 3 to 5 tons each and are arranged in batteries of 20 to 25 for each set of lead chambers. The daily charge for each furnace when the system is in operation is from 750 to 1,000 pounds of pyrites. The burners for the pyrites "fines" consist of cylindrical furnaces having a series of shelves so arranged that the burning material can be mechanically raked from shelf to shelf until the fully burned cinder is discharged at the bottom of the furnace. The rakes are attached to a central air or water cooled shaft. In one type of furnace the shaft revolves; in another the shaft is rigid while the furnace itself revolves.

The gases from the pyrites burners are forced into a dust chamber fitted with baffle plates where the oxides of iron, arsenic, lead, zinc, etc., are in a large measure removed. From the dust chamber the gases enter the Glover tower, which consists of a lead tower (usually from 20 to 30 feet high and 6 to 8 feet across) lined with acid-resisting brick and partly filled with quartz or other acid-proof material so arranged that the dilute nitrous vitriol which is distributed from an apparatus at the top of the tower will trickle down through the interstices. The heat of the burner gases which enter the Glover tower at a temperature of from $300^{\circ}$ to $400^{\circ} \mathrm{C}$. drives off water and the oxides of nitrogen from the nitrous vitriol, restoring them to the system. The uses of the Glover tower therefore are threefold: first, to cool the furnace gases before allowing them to enter the lead chambers; second, to restore water and the oxides of nitrogen to the system; and third, to produce an acid more concentrated than that formed in the lead chambers.

From the Glover tower the gases enter the first of the lead chambers where most of the sulphuric acid is made. The lead chambers usually consist of large square or oblong boxes ${ }^{1}$ made of sheet lead (weighing from 6 to 8 pounds per square foot) and having a capacity of from 25,000 to 75,000 cubic feet. Water in the form of fine spray or steam is introduced into the chambers at various points. This decomposes the nitrosulphuric acid formed into sulphuric acid and returns the oxides of nitrogen to the system to be again acted upon by the furnace gases. The number and size of the chambers used vary from 2 to 10 or more, depending on the number and size of the pyrites burners. Where the quantity of sulphur burned daily is large the acid plant is often divided into separate units, each battery of burners furnishing gases to its own set of lead chambers. The gases pass from the first to the second chamber and so on through

${ }^{1}$ In the Meyer Tangent system the lead chambers are cylindrical in form, while in the Falding system their height is several times their length and width. 
the system, sulphuric acid being formed till the sulphur dioxide is practically exhausted.

The residual gases, consisting of nitrogen, oxides of nitrogen, some oxygen, and a small percentage of sulphur dioxide, then enter the lower part of the Gay-Lussac or recovery tower, which is similar in construction to the Glover tower, except that it is usually taller and wider (from 40 to 50 feet high and 8 to 15 feet across) and filled with coke instead of quartz. Strong sulphuric acid (1.5 to 1.7 specific gravity) trickles down the tower, absorbing the oxides of nitrogen from the residual gases which ascend through the coke column, and are finally discharged through a stack. The nitrous vitriol formed is then pumped to the Glover tower, diluted with water, and distributed as previously described.

\section{IVEASUREMENT OF A PLANT'S EFFICIENCY.}

The efficiency of a lead-chamber plant is measured, first, by the amount of chamber space required for each pound of sulphur burned in 24 hours and the amount of acid $\left(50^{\circ}\right.$ or $60^{\circ}$ B.) made therefrom, and, second, by the amount of niter consumed or lost in the production of this acid.

Practically all sulpnurio acid authorities agree that, provided the gases are present in the proper proportions, the two most important conditions necessary for efficient production are a thorough mixing of the gases and the control of their temperature.

The importance of the first of these conditions is self-evident, since in order to bring about complete chemical reaction the reacting substances must be in intimate contact with one another. The second condition is important because too low a temperature lessens the chemical activity of the gases, while a temperature above $100^{\circ} \mathrm{C}$. prevents the condensation of water which it is claimed is necessary to bring about the decomposition of nitrosulphuric acid, an intermediate compound formed from the oxides of nitrogen in the system.

Numerous schemes to control these conditions have been devised, some of which have features of considerable interest and practical importance. While it is impracticable in a paper of this length to discuss in detail all of these processes, several that have been tried, apparently with some success, are described below.

\section{METHODS FOR ACCELERATING THE CHAMBER REACTIONS.}

Walter and Boeing ${ }^{1}$ advocate the use of several hollow acid-proof partitions built across the chambers and so arranged that the gases enter the compartments through large holes near the bottom and are discharged from holes near the top. Numerous other small holes 
allow the admission and exit of the gases, thereby causing them to mix intimately without seriously interfering with the draft.

Because of the doubtful stability of these inner walls and the serious damage caused on their collapse this method is no longer used.

Gossage ${ }^{1}$ as well as several other investigators proposed filling the chambers with coke so that the gases would be obliged to work their way through the interstices and thereby become thoroughly mixed. This scheme, however, has been abandoned because of the impurities introduced into the acid by the coke and the tendency of the coke columns to press against the lead walls, causing them to bulge and even break. The lack of any cooling device in this process also caused excessively high temperatures in the chambers.

Verstrart's ${ }^{2}$ plan is similar to the above, except that stacks of bottomless stoneware jars filled with coke are used. The oxides of nitrogen are supplied to the system by allowing nitric acid to trickle down one of the stacks.

In Pratt's ${ }^{3}$ process, which is much used in the Southern States, the gases are drawn through the first chamber by means of a fan, then through a tower packed with quartz down which flows dilute sulphuric acid, and finally they are reinjected into the front of the first chamber by means of the same fan. This circulatory system seems quite efficient and a number of plants where the process is employed are operating on less than 9 cubic feet of chamber space per pound of sulphur burned in 24 hours.

Meyer's ${ }^{4}$ tangental chambers are designed both to mix and to cool the reacting gases at the same time.

The chambers are cylindrical in form, the first having watercooled lead pipes suspended around the circumference. The gases are admitted at a tangent near the upper part of the chamber walls and are discharged from outlets in the centers of the chambers' bottoms. The gases are thus given a spiral motion which tends to mix them thoroughly while the water-cooled lead pipes reduce their temperature.

There are three installations of this type of plant in the United States. One at least is reported to have given great satisfaction.

Hartmann ${ }^{5}$ obtained an increased yield of acid in the lead-chamber process by placing vertical, air-cooled lead pipes in the chambers. The chamber bottom is turned up around the lower ends of these pipes, forming hydraulic seals, and thus obviating the necessity of joints in the bottom of the chamber.

${ }^{1}$ Lunge, Treatise on Manufacture of Sulphuric Acid, 1 Pt. I, p. 475.

2 Bull. Soc. encour. ind. nat., 1865, p. 531.

${ }^{3}$ U. S. patents Nos. $546,596,652,687$.

${ }^{4}$ English patent No. 18376: Zeit. für ang. Chem. (1900), p. 742.

5 Chem. Zeit., 1897 , p. 877. 
Blau ${ }^{1}$ proposed to cool the gases in the first chamber by injecting a spray of cold sulphuric acid, and in order to 8btain the optimum yield of acid from the gases in the subsequent chamber their temperature is raised by injecting sprays of warm sulphuric acid.

Falding's process ${ }^{2}$ has for its object the segregating of the active gases in a system. To accomplish this he employs a chamber the height of which is approximately one and one-half times greater than its horizontal dimensions. The burned gases after passing through the Glover tower in the usual way are introduced either near the top or lower down on the chamber's side. Since the fresh gases are hot, not only because they have recently issued from the pyrites burners but because of the reactions taking place between some of the constituents, they collect in the upper part of the chamber in a relatively active layer.

As the reactions subside the spent gases gradually cool and settle to the bottom of the chamber, where they are withdrawn. Falding claims that by using the high chamber a zone of great chemical activity is always maintained in the upper part of the chamber, and that the spent or inactive gases, which in ordinary chamber systems act as diluents, are continually being removed from the active zone. It is also claimed that much less chamber space is required to complete the reactions by this process, so that even where large volumes of gases are handled each chamber is a unit in itself, being connected directly with the Glover tower instead, of in series as in ordinary chamber systems.

A number of plants in this country are equipped with chambers of this type and it is reported that the process is commercially successful.

The main objections to the Falding system, in the opinion of the writer, are, first, that no provision is made for obtaining an intimate mixture of the gases other than the preliminary mixing brought about in the Glover tower, and, second, that no adequate means is provided for the condensation of the acid mist formed by the reactions.

The most widely used method of mixing and cooling the reacting gases is by means of intermediate towers containing plates, tubes, or baffles of some acid-resisting material cooled either by water, air, or dilute sulphuric acid. A number of different types of towers have been designed, but mention is here made of only a few of the better-known designs.

Lunge's plate tower ${ }^{3}$ consists of a shell of lead either cylindrical or angular in form and filled with a series of perforated plates laid,

\footnotetext{
1 German patent No. 95083.

2 U. S. patent 932771 (1909).

3 Treatise on Sulphuric Acid, vol. 1, Pt. I, pp. 478-498.
} 
horizontally. Each layer of plates is supported at some distance above the other by bearers in such a way that every plate is independent of the others. The plates are so constructed and placed that the holes in those of one layer do not come directly above the holes in the next layer below.

Dilute sulphuric acid is allowed to trickle down the tower, splashing from one layer of plates to another and meeting the hot-chamber gases as they wind upward through the tower. The film of dilute acid over the plates presents an immense cooling surface to the gases and at the same time furnishes the water necessary for the decomposition of the nitrosulphuric acid. The formation of this latter compound is, according to Lunge, a necessary link in the chamber process.

Gilchrist's pipe-column system ${ }^{1}$ consists of lead towers (3 or 4 feet across and 15 feet high) having corrugated lead tubes, open at both ends, running through them horizontally like a steam boiler. The sides of the towers are boxed in with boards so as to form an air shaft which terminates in a flue at the top.

The chamber gases, together with water vapor, enter the pipe columns at the sides near the bottom and work their way upward through the towers. Contact with the air-cooled corrugated tubes condenses the sulphuric acid, which then drips in showers from one series of pipes to another and frees the oxides of nitrogen, restoring them to the system. The gases issue from the top of the towers and enter the next chamber, from which they are drawn into another series of pipe columns, and so on through the system till their oxidation is practically complete.

While some of the methods just described are designed to cut down the amount of chamber space required, none of them, with the exception of Falding's process, reduces the initial cost of erecting an acid plant; for, while less lead may be employed in constructing the chambers, the expense of the cooling and mixing towers more than offsets the saving in chamber material.

Another objection to most of the accelerating devices discussed above is that in order to mix the gases thoroughly they must be drawn or forced through small openings or made to pursue a meandering course by means of baffles or some acid-proof packing material in the towers. Under such conditions dust or impurities may clog the apparatus, choking off the draft and making it necessary to clean out the tower or chamber before operations can be resumed. Moreover, the collapse or disarrangement of the packing material within the tower may cause even more serious trouble.

Nearly all modifications of the chamber process complicate somewhat the running of an acid plant, and should therefore be constantly under the supervision of a competent chemical engineer. 
In the new modification of the chamber method described in this publication a complete mixture of the gases and the control of their temperature is brought about without the use of expensive or complicated apparatus and with practically no danger of clogging the system. While this method has been tried out only in the laboratory, and some of the analytical data are not altogether satisfactory, the results obtained prove that the principle is good and that the process, if worked on a factory scale, would probably be commercially successful.

In a review of the patent literature on the subject an apparatus was found which is somewhat similar to the one herein described. This United States patent (No. 446060) was taken out by E. and J. Delplace in 1891 and consists of a lead chamber having the shape of a ring with a sector cut out. The chamber is provided with two gas inlets at unequal distances from the center and contains at intervals distributing pipes leading from the upper part to the lower part of the chamber, so that the hot gases can be more thoroughly mixed with the cooler. The inventors state that in such a chamber the constant change in the direction of the gases and their impinging on the sides of the chamber cause a thorough mixture and a condensation of the acid formed. In this patent the right is reserved to vary the shape of the chamber provided the gases are led through a circular route.

The main objections to the above apparatus, in the opinion of the writer, are, first, that the chamber as described is of such a size that there must be spaces therein where the gases are relatively inactive; second, the pipes for conveying the hotter gases from the upper to the lower part of the chamber. would hardly accomplish this unless they were the only route provided for the passage of the gases, and this according to the specifications is not the case; third, the use of pipes within the lead chamber unless they are cooled is always objectionable because of their excessive corrosion and the serious consequences resulting therefrom; fourth, a chamber of the shape described occupies an enormous amount of ground space. Where land values are high, this entails a large outlay for a factory site, as well as an expensive building to house the chamber.

\section{NEW MODIFICATION OF THE CHAMBER PROCESS. ${ }^{1}$}

This method is based on the fact that if a mixture of warm gases is drawn downward through a special flue their resistance to the downward pull, together with the constant change of their course, will tend to mix them very intimately, and unless the internal diameter of the flue is too great there will be practically no zones of inac-

1 Work carried on under the direction of Dr. F. K. Cameron, to whom the author is indebted for much valuable assistance.

527ํ-ull. $283-15-2$ 
tirity in the apparatus. Moreorer, the constant impinging of the gases on the walls of the spiral flue, which can be cooled either by air or water, makes it practicable to maintain the gases at a temperature most farorable for the efficient yield of sulphuric acid.

In the following laboratory experiments, howerer, the sulphur dioxide $\left(\mathrm{SO}_{2}\right)$ used was not directly derired from burning prrites or sulphur, so it was necessary to heat the system artificially to attain a temperature as high as that obtained under factory conditions.

The sulphur dioxide was obtained from a small cylinder of the liquefied gas, which was weighed both before and after each experiment, and the $\mathrm{SO}_{2}$ used thus determined. The oxides of nitrogen (chiefl $\mathrm{N}_{2} \mathrm{O}_{3}$ and $\mathrm{N}_{2} \mathrm{O}_{4}$ ) were produced by the action of dilute nitric acid on copper, and the rate at which they were used was roughly

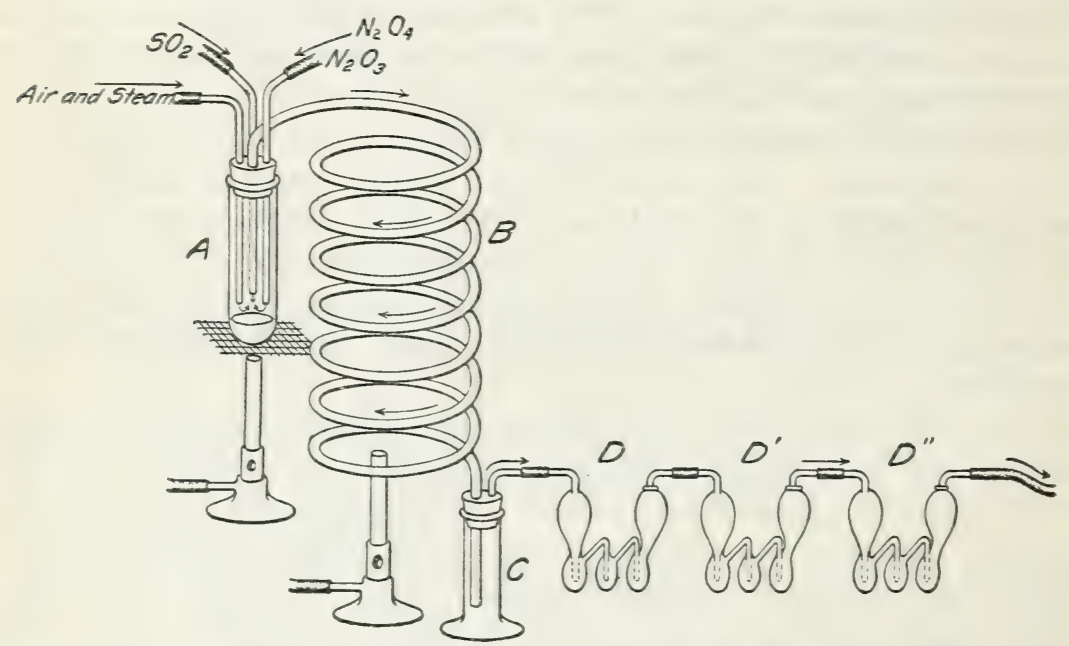

FIG. 1.-Apparatus used in proposed new method for manufacture of sulphuric acid.

determined by allowing the gases to bubble through dilute sulphuric acid saturated with these gases. A mixture of air and water rapor was obtained br drawing air through a flask of water heated to the boiling point.

The apparatus emplored (fig. 1) consisted, first, of a large test tube (A), haring a capacity of 200 c.c., and containing a little water heated to boiling. The oxides of nitrogen, sulphur dioxide, air, and water rapor were led to the bottom of this ressel by separate tubes and given a preliminary mixing. From the test tube the gases were drawn into the lead or glass spiral (B), which was heated to about $90^{\circ} \mathrm{C}$. in order to facilitate the reactions. In winding downward through this spiral the warm gases were thoroughly mixed, with the result that most of the sulphuric acid produced in the system was formed in this coil. The residual gases were then passed through 
the absorption bulbs (D, $\left.\mathrm{D}^{\prime}, \mathrm{D}^{\prime \prime}\right)$ containing strong nitric acid, which absorbed the sulphur dioxide escaping oxidation in the spiral.

The quantities of sulphur dioxide converted into sulphuric acid in the tube (A) and the spiral (B), as well as that which escaped oxidation and was subsequently absorbed in the bulbs $\left(\mathrm{D}, \mathrm{D}^{\prime}, \mathrm{D}^{\prime \prime}\right)$, were determined by analyses. The results of these analyses are given in Tables II and III.

When the lead spiral was used (Table II), the amount of sulphuric acid formed therein had to be determined by difference because of the formation of lead sulphate, which could not be entirely removed from the tube by washing.

On account of the many joints and rubber connections necessary in the apparatus there was some loss of sulphur dioxide in the system. When the lead spiral was used, the amount of this loss could not be determined, so all the errors occurring in Table II are thrown into column 5, making the figures for the sulphur dioxide oxidized in the lead spiral larger than they actually should be.

TABLE II.-Sulphur dioxide oxidized to sulphuric acid in apparatus shown in figure 1. Lead spiral used and steady stream of oxides of nitrogen furnished throughout experiments.

\begin{tabular}{|c|c|c|c|c|c|c|}
\hline \multirow{2}{*}{ Number of run. } & \multirow{2}{*}{$\begin{array}{l}\text { Time of } \\
\text { run. }\end{array}$} & \multirow{2}{*}{$\begin{array}{l}\text { Rate per } \\
\text { hour of } \\
\mathrm{SO}_{2} \text {. }\end{array}$} & \multicolumn{2}{|c|}{$\begin{array}{l}\mathrm{SO}_{2} \text { oxidized in } \\
\text { system. }\end{array}$} & \multirow{2}{*}{$\mid \begin{array}{c}\mathrm{SO}_{2} \text { lost } \\
\text { in } \\
\text { system. } 1\end{array}$} & \multirow{2}{*}{$\begin{array}{c}\mathrm{SO}_{2} \\
\text { escaping } \\
\text { from en } \\
\text { of spiral }\end{array}$} \\
\hline & & & $\begin{array}{c}\text { In vessel } \\
\text { A. }\end{array}$ & $\begin{array}{l}\text { In lead } \\
\text { spiral B. }\end{array}$ & & \\
\hline $\begin{array}{l}5 \\
7 \\
8\end{array}$ & $\begin{array}{r}\text { Hours. } \\
2 \\
2 \\
2\end{array}$ & $\begin{array}{r}\text { Grams. } \\
6.2017 \\
6.4887 \\
7.6569\end{array}$ & $\begin{array}{r}\text { Per cent. } \\
32.07 \\
26.61 \\
23.00\end{array}$ & $\begin{array}{r}\text { Per cent. } \\
67.92 \\
73.39 \\
76.99\end{array}$ & & $\begin{array}{r}\text { Percent. } \\
0.01 \\
\text { Trace } \\
.01\end{array}$ \\
\hline
\end{tabular}

1 Could not be determined. Included in the figures in column 5.

An inspection of Table II shows that by passing sulphur dioxide, air, and water vapor through a lead spiral in the presence of an adequate supply of the oxides of nitrogen, the formation of sulphuric acid is practically complete, even when the gases are run at quite a rapid rate.

In ordinary chamber plants it is considered very good practice if only 10 feet of chamber space is required for every pound of sulphur burned in 24 hours. Figuring the chamber space required in run No. 8 , it is seen that for every pound of sulphur burned in 24 hours only 0.139 foot of chamber space was required.

While it is hardly fair to compare the results obtained in the laboratory with those obtained on a factory scale, still the efficiency of the apparatus can be more readily judged by expressing the results in the conventional way.

The well-known characteristic of some metals, as well as metallic oxides and salts, of acting as catalytic agents made it seem possible 
that the lead, lead oxide; or lead sulphate had something to do with the rery efficient rield of acid obtained when using the lead spiral. Accordinglr, a glass coil of the same length and internal diameter $\pi$ as substituted in the experiments shown in Table III.

TABLE III.-Sulpt:ur dioxide ondised to sulphuric acid in apparatus shoun in figure 1. Glass spiral used and steady stream of oxides of nitrogen furnished.

\begin{tabular}{|c|c|c|c|c|c|c|}
\hline \multirow{2}{*}{ Number of run. } & \multirow{2}{*}{$\begin{array}{l}\text { Time of } \\
\text { run. }\end{array}$} & \multirow{2}{*}{$\begin{array}{l}\text { Rate per } \\
\text { hour of } \\
\mathrm{SO}_{2} \text {. }\end{array}$} & \multicolumn{2}{|c|}{$\begin{array}{l}\mathrm{SO}_{2} \text { oxidized in } \\
\text { system. }\end{array}$} & \multirow{2}{*}{$\begin{array}{l}\mathrm{SO}_{2} \text { lost } \\
\text { in } \\
\text { system. }\end{array}$} & \multirow{2}{*}{$\begin{array}{l}\mathrm{SO}_{2} \\
\text { escaping } \\
\text { from end } \\
\text { of spiral. }\end{array}$} \\
\hline & & & $\begin{array}{c}\text { In ressel } \\
\text { A. }\end{array}$ & $\begin{array}{l}\text { In glass } \\
\text { spiral B. }\end{array}$ & & \\
\hline $\begin{array}{l}20 \ldots \ldots \\
19 \ldots \ldots \\
12 \ldots \ldots\end{array}$ & $\begin{array}{r}\text { Hours. } \\
1 \frac{1}{2} \\
1 \frac{1}{2} \\
2\end{array}$ & $\begin{array}{l}\text { Grams. } \\
3.5311 \\
4.6404 \\
5.7888\end{array}$ & $\begin{array}{r}\text { Per cent. } \\
14.17 \\
43.99 \\
20.18\end{array}$ & $\begin{array}{r}\text { Percent. } \\
75.14 \\
50.19 \\
71.66\end{array}$ & $\begin{array}{l}3.15 \\
3.20 \\
1.26\end{array}$ & $\begin{array}{r}\text { Per cent. } \\
7.31 \\
2.63 \\
6.28\end{array}$ \\
\hline
\end{tabular}

Table III shows that the rield of acid was not so great with a glass as it was with a lead spiral. In no instance was the gas run through the apparatus so fast as in the experiments in Table II, ret eren though the oxides of nitrogen $\pi$ ere present in large quantities in the gaseous mixture there was a loss of sulphur dioxide from the end of the spiral.

In order to try out the catalytic action of the lead coil, sereral runs were made with both the glass and lead spirals, but using no oxides of nitrogen. The results of these experiments are shown in Tables IV and V.

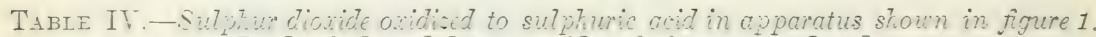
Lead spiral used, but no oxides of nitrogen employed.

\begin{tabular}{|c|c|c|c|c|c|c|}
\hline \multirow{2}{*}{ Number of run. } & \multirow{2}{*}{$\begin{array}{l}\text { Time of } \\
\text { run. }\end{array}$} & \multirow{2}{*}{$\begin{array}{l}\text { Rate per } \\
\text { hour of } \\
\mathrm{SO}_{2} \text {. }\end{array}$} & \multicolumn{2}{|c|}{$\begin{array}{l}\mathrm{SO}_{2} \text { oxidized in } \\
\text { system. }\end{array}$} & \multirow{2}{*}{$\begin{array}{l}\mathrm{SO}_{2} \text { lost } \\
\text { in } \\
\text { system. } 1\end{array}$} & \multirow{2}{*}{$\begin{array}{c}\mathrm{SO}_{2} \\
\text { escaping } \\
\text { from end } \\
\text { of spiral. }\end{array}$} \\
\hline & & & $\begin{array}{c}\text { In vessel } \\
\mathrm{A} .\end{array}$ & 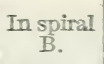 & & \\
\hline & $\begin{array}{r}\text { Hours. } \\
\frac{1}{1}\end{array}$ & $\begin{array}{c}\text { Grams. } \\
3.26 \pm 2 \\
3.8159\end{array}$ & $\begin{array}{r}\text { Per cent. } \\
0.40 \\
.41\end{array}$ & $\begin{array}{r}\text { Per cent. } \\
33.08 \\
40.79\end{array}$ & $\begin{array}{c}\text { Per cent. } \\
\\
\end{array}$ & $\begin{array}{r}\text { Pet cont. } \\
61.52 \\
58.81\end{array}$ \\
\hline
\end{tabular}

1 Could not be determined. Included in figures in column s.

TABIL T.-Sulphur dionide oridized to sulphuric acid in apparatus shoun in figure 1. Glass spiral used, but no oxides of nitrogen employed.

\begin{tabular}{|c|c|c|c|c|c|c|}
\hline \multirow{2}{*}{ Sumi er o: rum. } & \multirow{2}{*}{$\begin{array}{l}\text { Time of } \\
\text { run. }\end{array}$} & \multirow{2}{*}{$\begin{array}{l}\text { Rate per } \\
\text { bour of } \\
\text { SO_. }\end{array}$} & \multicolumn{2}{|c|}{$\begin{array}{l}\mathrm{SO}_{2} \text {. oxidized in } \\
\text { system. }\end{array}$} & \multirow{2}{*}{$\begin{array}{l}\mathrm{SO}_{2} \text { lost } \\
\text { in } \\
\text { system. }\end{array}$} & \multirow{2}{*}{$\begin{array}{l}\mathrm{SO}_{3} \\
\text { escaping } \\
\text { from end } \\
\text { of spiral. }\end{array}$} \\
\hline & & & $\begin{array}{c}\text { In ressel } \\
t .\end{array}$ & $\begin{array}{c}\text { In spiral } \\
\text { B. }\end{array}$ & & \\
\hline $\begin{array}{l}18 . \\
15 .\end{array}$ & $\begin{array}{r}\text { Hours. } \\
10 \\
10\end{array}$ & $\begin{array}{l}\text { Grams. } \\
2.6713 \\
2.8393\end{array}$ & $\begin{array}{l}\text { Per cent. } \\
\text { (1) } \\
0.40\end{array}$ & $\begin{array}{r}\text { Per cent. } \\
0.75 \\
0.68\end{array}$ & $\begin{array}{l}\text { Per cent. } \\
210.02 \\
212.36\end{array}$ & $\begin{array}{r}\text { Per cent. } \\
89.23 \\
86.56\end{array}$ \\
\hline
\end{tabular}

\footnotetext{
${ }_{1}^{1}$ Included in next column.

2 The lan -e loss of sulnhur cioxihe in the svstem was due in nor: to the renewnl of the sulphuric acid in

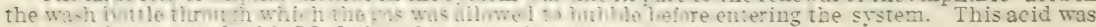
not entirely saturated with $\mathrm{SO}_{3}$ before these experiments were undertaken.
} 
In comparing the results obtained in Tables IV and V it is evident that the lead spiral had some influence in the oxidization of the sulphur dioxide to sulphuric acid. The figures in column 5, Table IV, are obviously too high since all the errors due to the loss of gas in the system are thrown into this column. But while the sulphur dioxide and air was in each instance run through the lead spiral at greater speed than through the glass coil, the quantity escaping oxidation was much less in the former than in the latter case.

In order to determine if the catalytic action observed in the lead coil was due to lead or lead sulphate, two experiments were conducted using the glass spiral but no oxides of nitrogen. The conditions in these experiments were approximately the same as in those recorded in Table $\mathrm{V}$ except that in the first run the interior of the glass coil was coated with precipitated lead sulphate and in the second a lead chain was introduced into the glass spiral. The results are shown in Table VI.

TABLE VI.-Sulphur dioxide oxidized to sulphuric acid in glass spiral coated with lead sulphate and in the same spiral after the introduction of a lead chain.

\begin{tabular}{|c|c|c|c|c|c|c|c|}
\hline \multirow{2}{*}{ Number of run. } & \multirow{2}{*}{$\begin{array}{l}\text { Time of } \\
\text { run. }\end{array}$} & \multirow{2}{*}{$\begin{array}{l}\text { Coil } \\
\text { used. }\end{array}$} & \multirow{2}{*}{$\begin{array}{l}\text { Rate per } \\
\text { hour of } \\
\mathrm{SO}_{2} \text {. }\end{array}$} & \multicolumn{2}{|c|}{$\begin{array}{l}\mathrm{SO}_{2} \text { oxidized in } \\
\text { system. }\end{array}$} & \multirow{2}{*}{$\begin{array}{l}\mathrm{SO}_{2} \text { lost } \\
\text { in } \\
\text { system. }\end{array}$} & \multirow{2}{*}{$\begin{array}{c}\mathrm{SO}_{2} \\
\text { escaping } \\
\text { from end } \\
\text { of spiral. }\end{array}$} \\
\hline & & & & $\begin{array}{c}\text { In vessel } \\
\mathrm{A} .\end{array}$ & In spiral & & \\
\hline $\begin{array}{l}22 \ldots \ldots \\
23 \ldots \ldots \\
24 \ldots \ldots\end{array}$ & $\begin{array}{r}\text { Hours. } \\
1.0 \\
1.0 \\
1.5\end{array}$ & $\begin{array}{l}(1) \\
(3) \\
(1)\end{array}$ & $\begin{array}{r}\text { Grams. } \\
2.6594 \\
1.7523 \\
2.5299\end{array}$ & $\begin{array}{r}\text { Per cent. } \\
0.25 \\
0.09 \\
0.05\end{array}$ & $\begin{array}{r}\text { Per cent. } \\
9.80 \\
53.60 \\
17.85\end{array}$ & $\begin{array}{c}\text { Per cent. } \\
(2) \\
(2) \\
(2)\end{array}$ & $\begin{array}{r}\text { Per cent. } \\
\quad 39.95 \\
46.31 \\
82.10\end{array}$ \\
\hline
\end{tabular}

1 Class coil coated with lead sulphate.

2 Not determined.

3 Glass coil containing lead chain.

Here again, as in Tables II and IV, the amount of sulphur dioxide lost in the system could not be determined, but the results shown in Table VI indicate that while lead sulphate has some influence on the oxidation of sulphur dioxide, lead or lead oxide is a much more energetic catalytic agent. The presence of the oxides of nitrogen in the system, however, is necessary for the complete oxidation of sulphur dioxide to sulphuric acid.

\section{FACTORY CONSIDERATIONS.}

In the construction of a sulphuric acid plant along the lines of the apparatus described in this paper, it is proposed to dispense with the lead chambers and intermediate towers only. The lead spiral is not intended to replace the Glover tower, which is so important in the preliminary mixing and cooling of the furnace gases and in restoring the oxides of nitrogen to the system, nor is it intended to do away with the Gay-Lussac tower, which is essential for the recovery of these same oxides of nitrogen from the residual gases. 
The amount of lead required per cubic foot of chamber space is considerably greater for a long spiral tube as herein suggested than for a crlindrical chamber in which the height and diameter are more nearly equal, but the great reduction in the chamber space required to produce sulphuric acid in the spiral should make it possible to build a plant with considerably less lead than is required in an ordinarr chamber system. Moreorer, the facts that the new trpe of plant requires no other derice to accelerate the reactions and occupies much less ground space than the present type of factory, and therefore would not need large buildings, should decrease the initial cost of construction.

The cooling of the lead spiral would be accomplished largely by the air, but if necessary in hot weather streams of water could be plared upon its upper portion. The water thus warmed by the heat of the reaction of the upper part of the spiral would tend to raise the temperature of the lower portion of the spiral where the reactions are not so rigorous. The immense amount of cooling surface contained in such a spiral, together with the constant movement of the acting gases, should also prevent excessire corrosion of the lead walls.

Thile it is not fair, and hardly practicable, to predict how efficient a plant built along the lines of the apparatus just described would prove, all the indications are that such a scheme, worked on a factory scale, would be economically successful.

In the following tables the author has attempted to classify all the American patents on the manufacture of sulphuric acid, both by the contact and chamber processes. While these classifications are by no means drawn along sharp and distinct lines, still they should be of considerable assistance in enabling one to pick out the particular phase of acid manufacture which interests him most.

In tabulating and abstracting these patents it is probable that numerous important points hare been omitted, but in many cases this was unavoidable because of the limited space arailable in tables of this character. It is thought, however, that the information given will enable those interested in the subject to judge fairly well whether or not any particular patent is of sufficient value to him to warrant further investigation.

Tote.-Application has been made for a patent covering the process here described; if patent is allowed, it will be donated to the people of the United States. 
PRODUCTION OF SULPHURIC ACID.

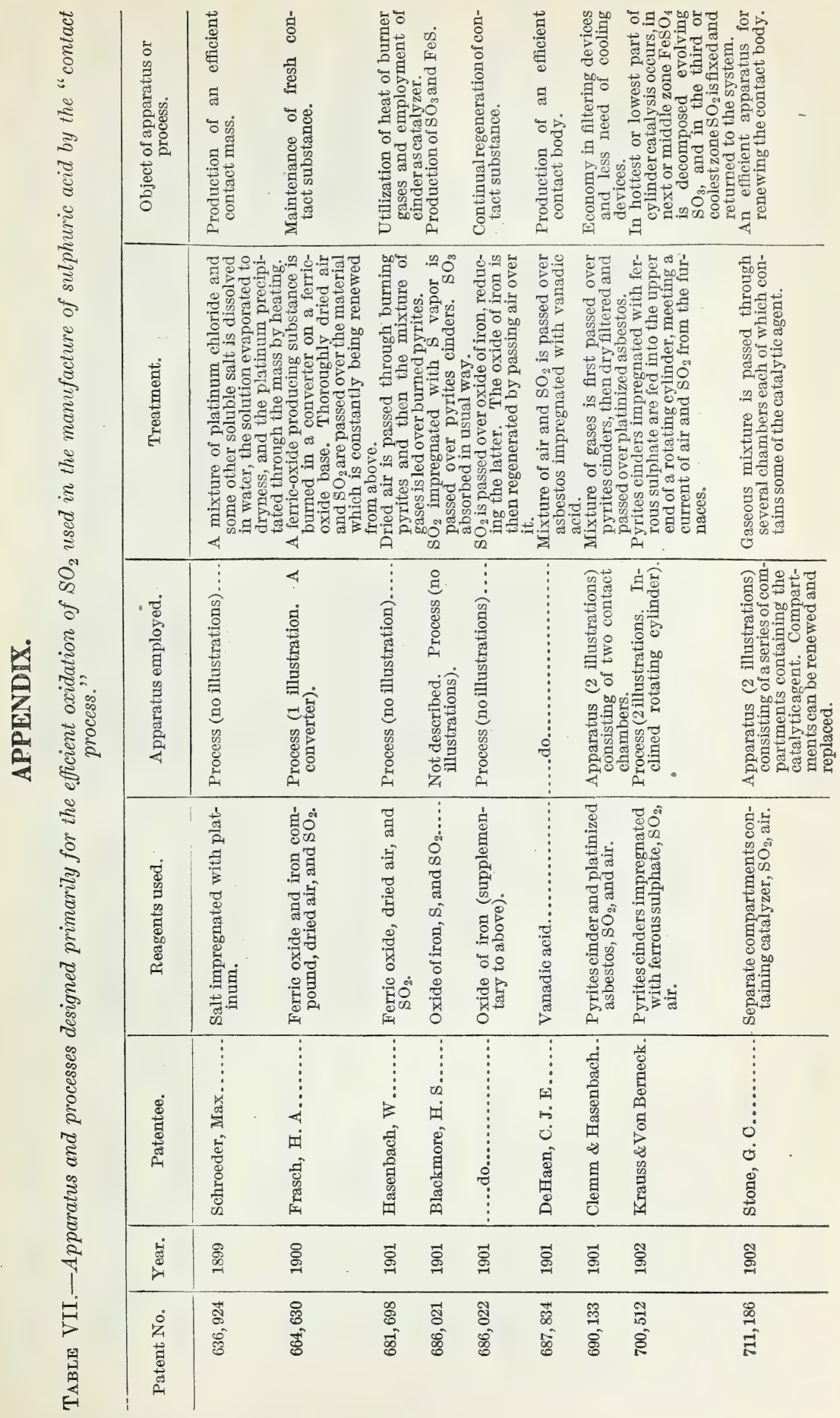




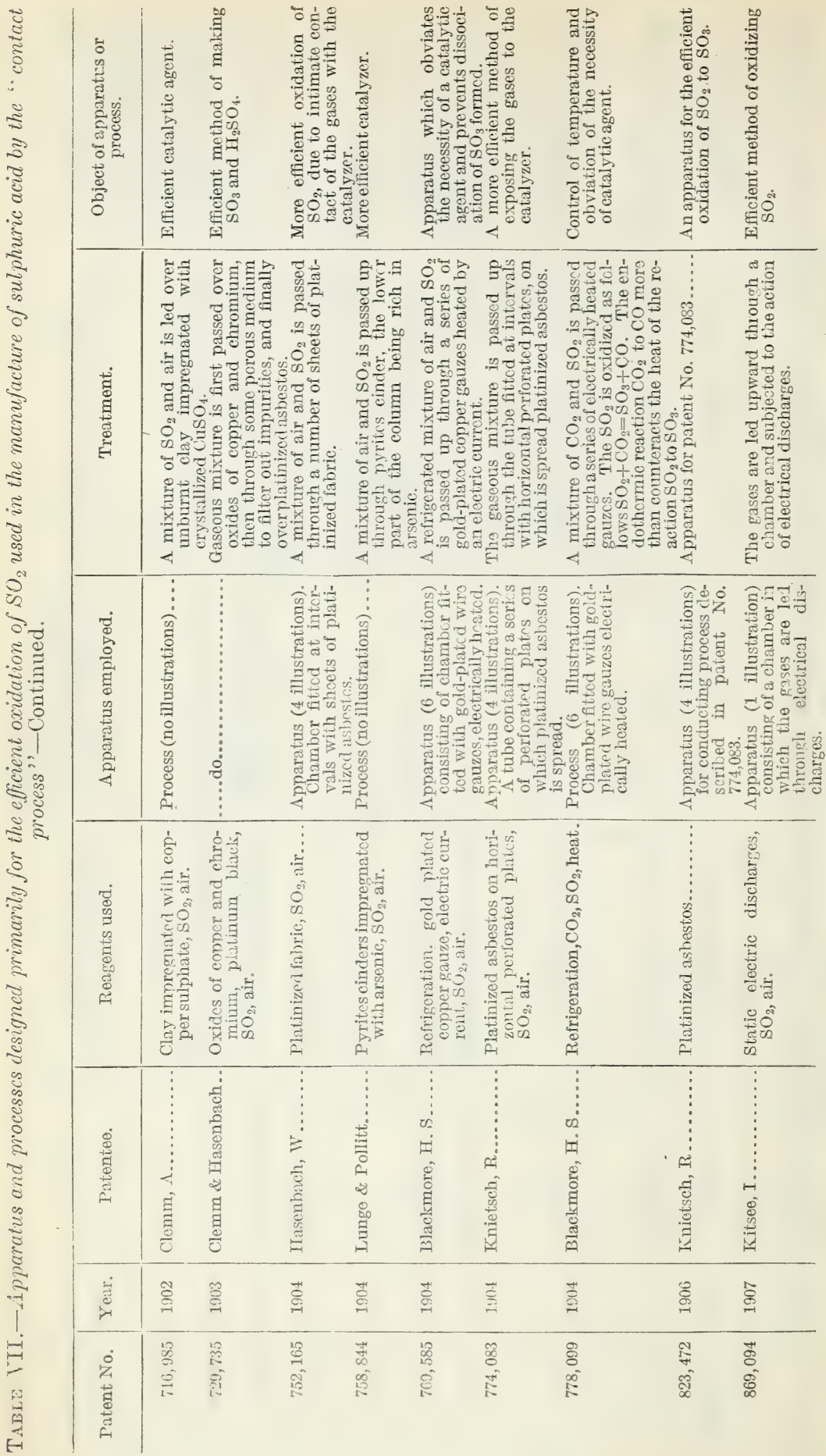




\begin{tabular}{|c|c|c|c|c|}
\hline 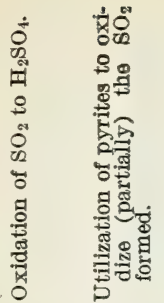 & 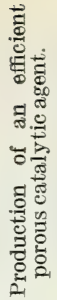 & 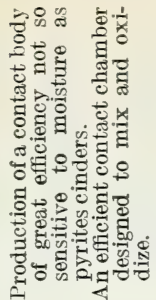 & 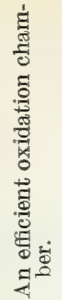 & 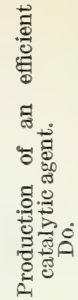 \\
\hline
\end{tabular}

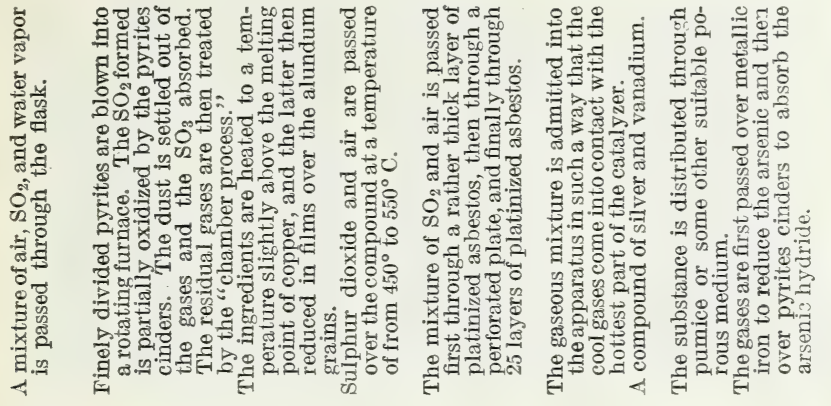

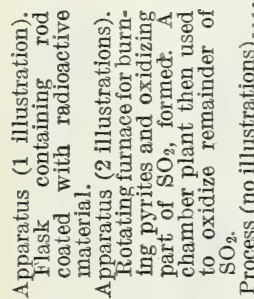

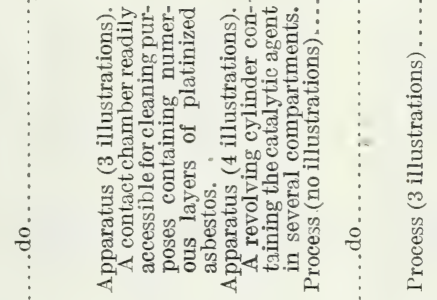

\begin{tabular}{|c|c|c|c|c|c|c|c|}
\hline 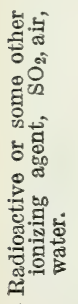 & 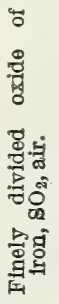 & 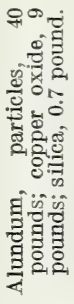 & 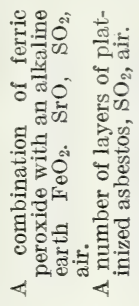 & 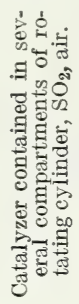 & 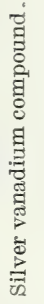 & 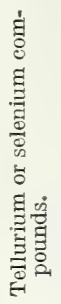 & 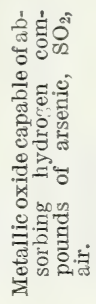 \\
\hline 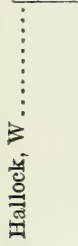 & 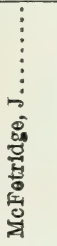 & 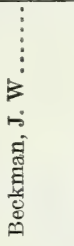 & 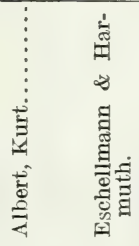 & 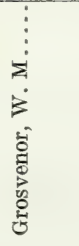 & 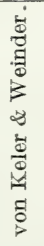 & 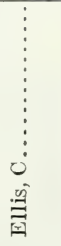 & 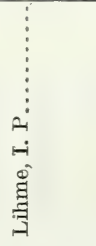 \\
\hline 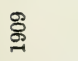 & $\overrightarrow{9}$ & $\bar{\sigma}$ & $\stackrel{\sim}{\sigma}$ & 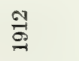 & $\underset{\sim}{\stackrel{H}{S}}$ & 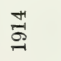 & $\vec{\sigma}$ \\
\hline 둥 & $\begin{array}{l}\text {. } \\
\text { डै } \\
\text { \% } \\
\text { व. }\end{array}$ & $\stackrel{40}{\circ}$ & 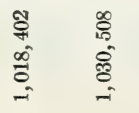 & $\begin{array}{l}\circ \\
0 \\
0 \\
0 \\
0 \\
-1\end{array}$ & $\begin{array}{l}\stackrel{8}{0} \\
\text { व. } \\
\text { of } \\
\stackrel{-1}{-1}\end{array}$ & 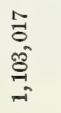 & 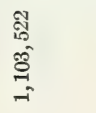 \\
\hline
\end{tabular}




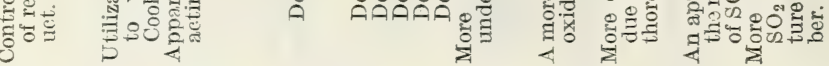

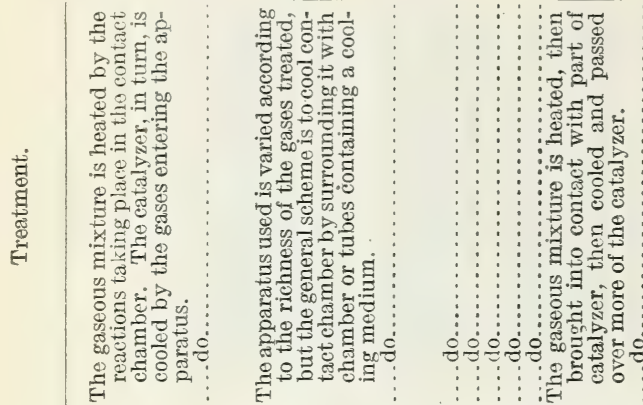

\begin{tabular}{|c|c|}
\hline 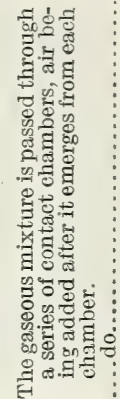 & 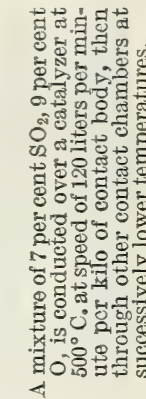 \\
\hline
\end{tabular}

(2)

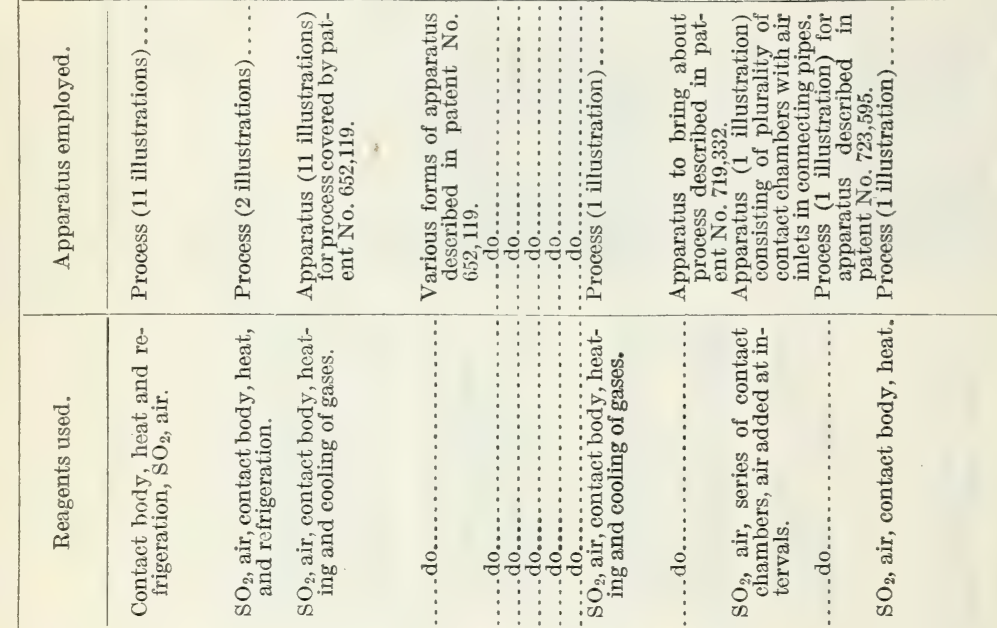

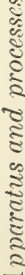

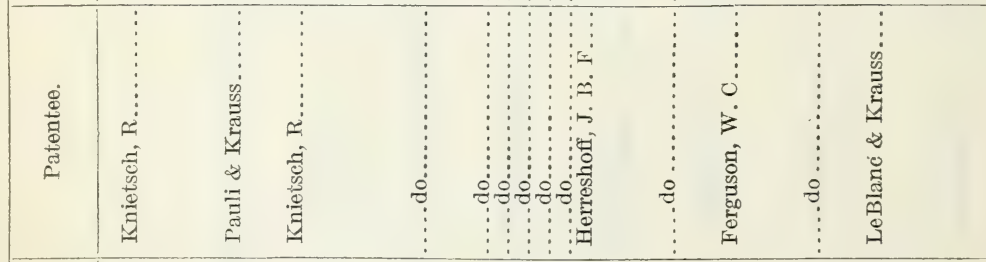

西

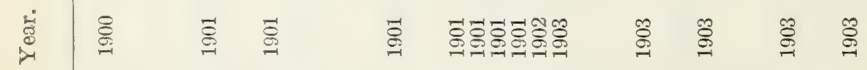

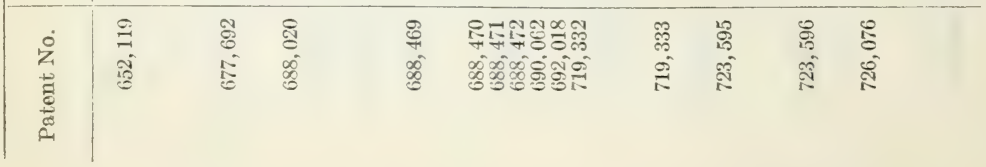




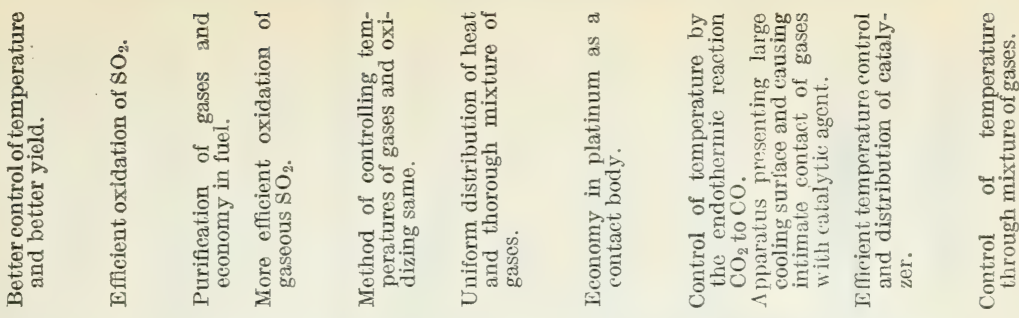

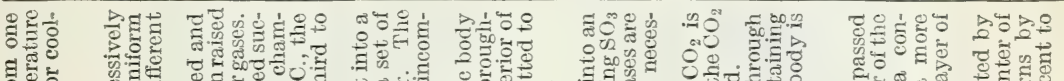
o. ñ. 50.0. 目

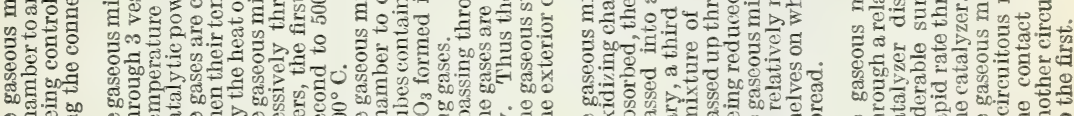

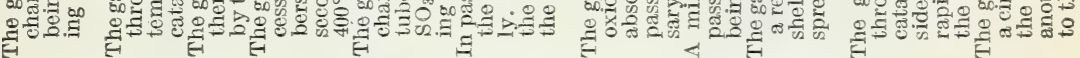
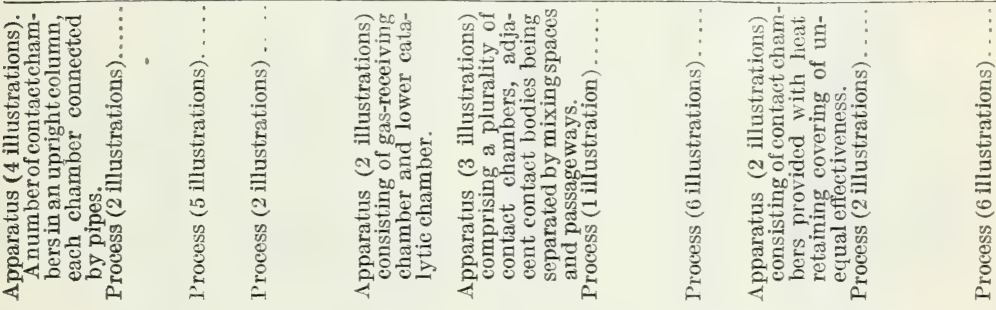

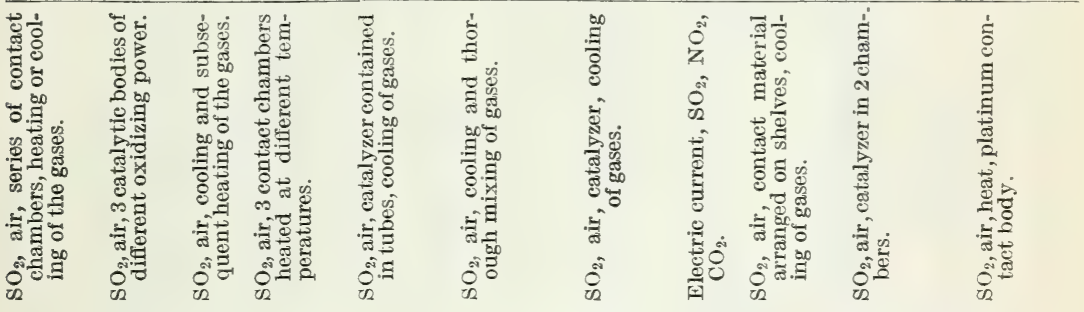

\begin{tabular}{|c|c|c|c|c|c|c|c|c|c|c|}
\hline $\begin{array}{c}\vdots \\
\vdots \\
\vdots \\
\vdots \\
\tilde{\Xi} \\
\AA\end{array}$ & 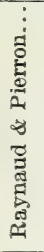 & 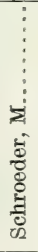 & 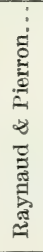 & 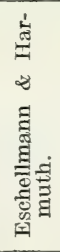 & 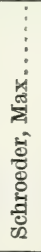 & 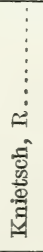 & 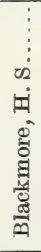 & 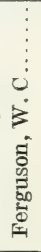 & 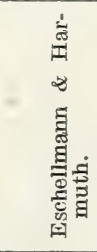 & 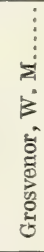 \\
\hline ఫ్త్తి & 怘 & 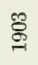 & 芯 & $\stackrel{\text { }}{\Phi}$ & $\stackrel{20}{\mathscr{E}}$ & $\stackrel{్}{\leftrightarrows}$ & \& & $\stackrel{Ð}{\Phi}$ & $\stackrel{\Xi}{\Xi}$ & పี \\
\hline$\stackrel{\infty}{\circ}$ & $\begin{array}{l}\text { D. } \\
\infty \\
0 \\
0 \\
0\end{array}$ & 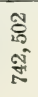 & $\begin{array}{l}\text { F } \\
\text { है }\end{array}$ & 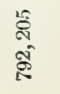 & 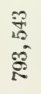 & 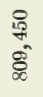 & \begin{tabular}{l}
$\infty$ \\
\multirow{2}{*}{} \\
$\infty$ \\
$\infty$ \\
$\infty$
\end{tabular} & $\begin{array}{l}\mathscr{D} \\
\infty \\
0 \\
\infty \\
\infty\end{array}$ & 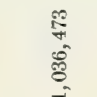 & $\begin{array}{l}\text { : } \\
0 \\
0\end{array}$ \\
\hline
\end{tabular}


20 BUlletin 283, U. S. Department of AGRICUlture.

\begin{tabular}{|c|c|c|}
\hline 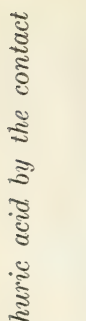 & 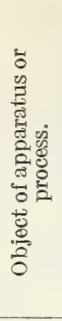 & 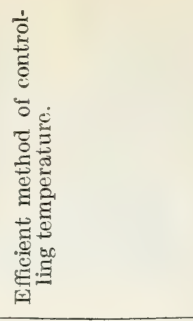 \\
\hline 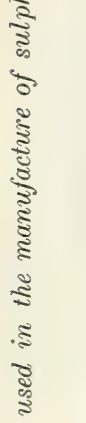 & 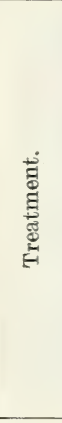 & 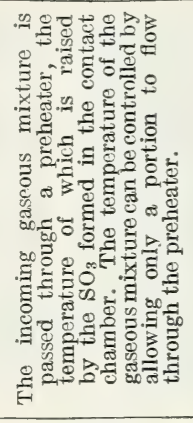 \\
\hline 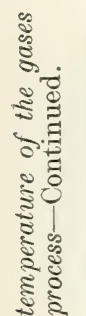 & 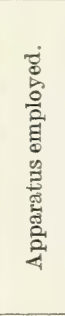 & 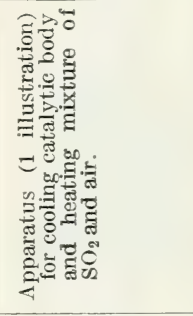 \\
\hline 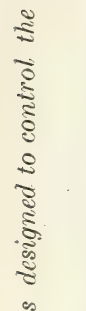 & 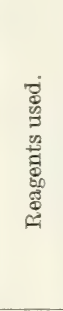 & 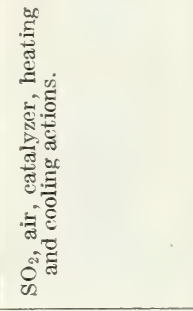 \\
\hline 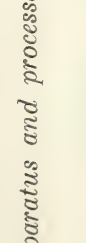 & 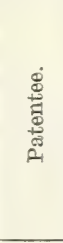 & $\begin{array}{l}E \\
E \\
E\end{array}$ \\
\hline 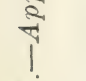 & 庐 & $\underset{\Xi}{\vec{\sigma}}$ \\
\hline 5 & 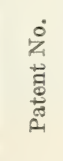 & 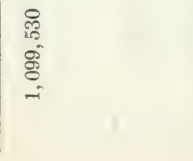 \\
\hline
\end{tabular}


PRODUCTION OF SULPHURIC ACID.

\begin{tabular}{|c|c|c|c|c|c|c|c|c|c|}
\hline 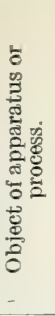 & 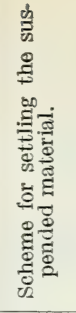 & 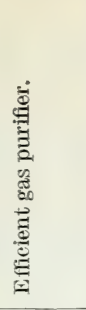 & 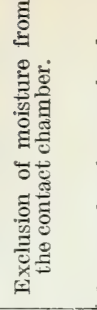 & 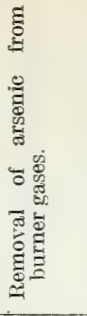 & $\dot{8}$ & 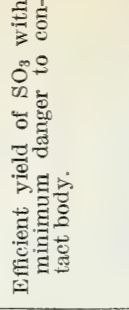 & 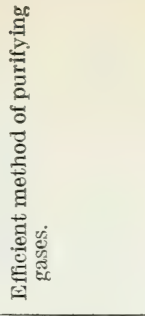 & 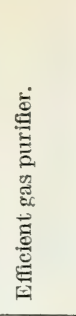 & 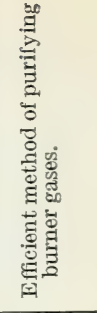 \\
\hline 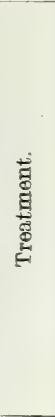 & 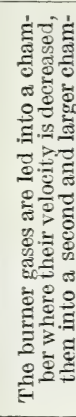 & 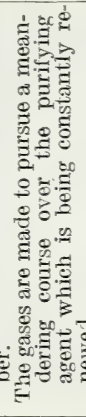 & 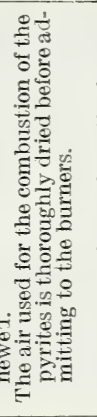 & 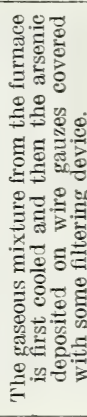 & 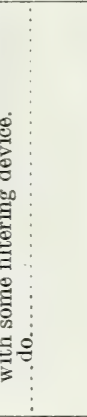 & 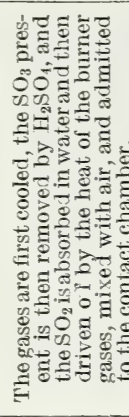 & 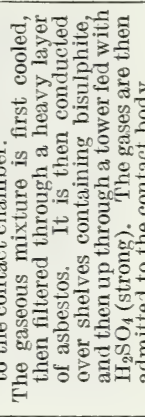 & 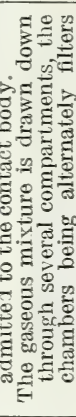 & 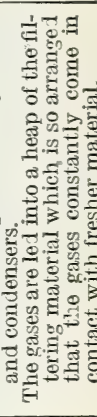 \\
\hline 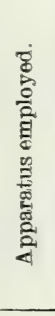 & 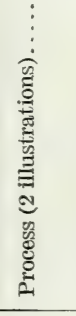 & 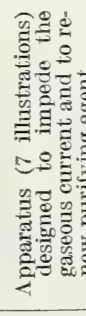 & 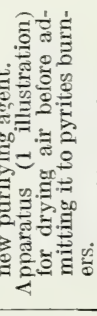 & 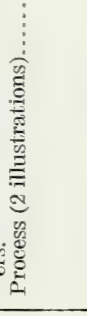 & 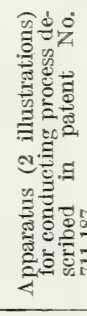 & 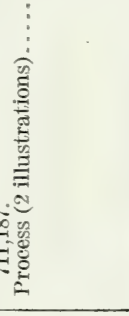 & 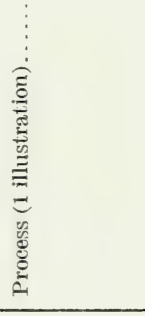 & 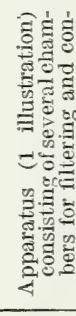 & 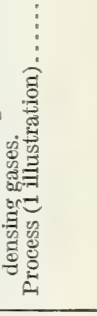 \\
\hline 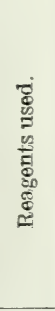 & 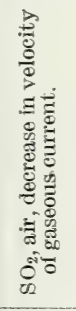 & 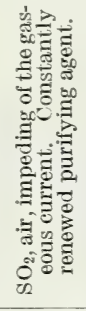 & 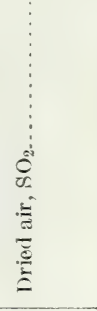 & 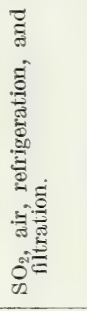 & $\frac{1}{1}$ & 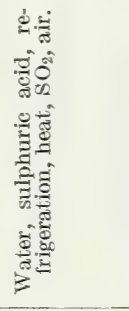 & 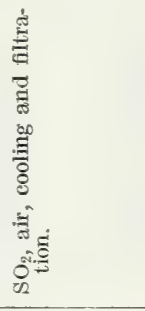 & 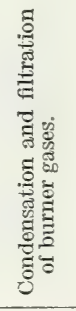 & 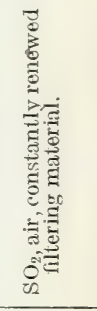 \\
\hline
\end{tabular}

\begin{tabular}{|c|c|c|c|c|c|c|c|c|c|}
\hline 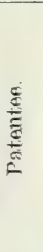 & 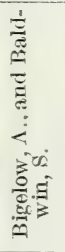 & 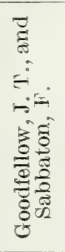 & 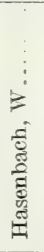 & 递 & $\begin{array}{c}\vdots \\
\vdots \\
\vdots \\
\vdots \\
\vdots \\
\vdots\end{array}$ & $\begin{array}{c}\vdots \\
\vdots \\
\vdots \\
\tilde{y}\end{array}$ & 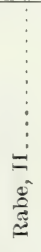 & $\begin{array}{c} \\
\vdots \\
\vdots \\
\vdots \\
0 \\
0 \\
0 \\
\frac{0}{02}\end{array}$ & 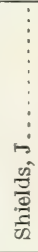 \\
\hline 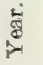 & $\underset{\sim}{\mathbb{\infty}}$ & 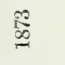 & 点 & 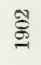 & $\stackrel{\vartheta}{~}$ & 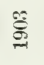 & $\stackrel{\tilde{F}}{\stackrel{\tilde{E}}{-}}$ & 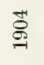 & 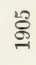 \\
\hline $\begin{array}{l}\dot{c} \\
\frac{\dot{z}}{\vec{a}} \\
\frac{\vec{a}}{c}\end{array}$ & $\begin{array}{l}\hat{\tilde{E}} \\
\tilde{s}\end{array}$ & $\begin{array}{l}\text { 范 } \\
\stackrel{5}{0} \\
\end{array}$ & 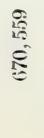 & $\begin{array}{l}\vec{D} \\
\vec{E} \\
\vec{E}\end{array}$ & $\begin{array}{l}\underset{\infty}{a} \\
\stackrel{=}{\rightleftarrows}\end{array}$ & 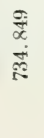 & 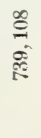 & $\begin{array}{l}\text { Wू } \\
\text { 尺े } \\
\text { 总 }\end{array}$ & 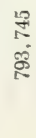 \\
\hline
\end{tabular}


BULlETIN 283, U. S. DEPARTMENT OF AGRICULTURE.

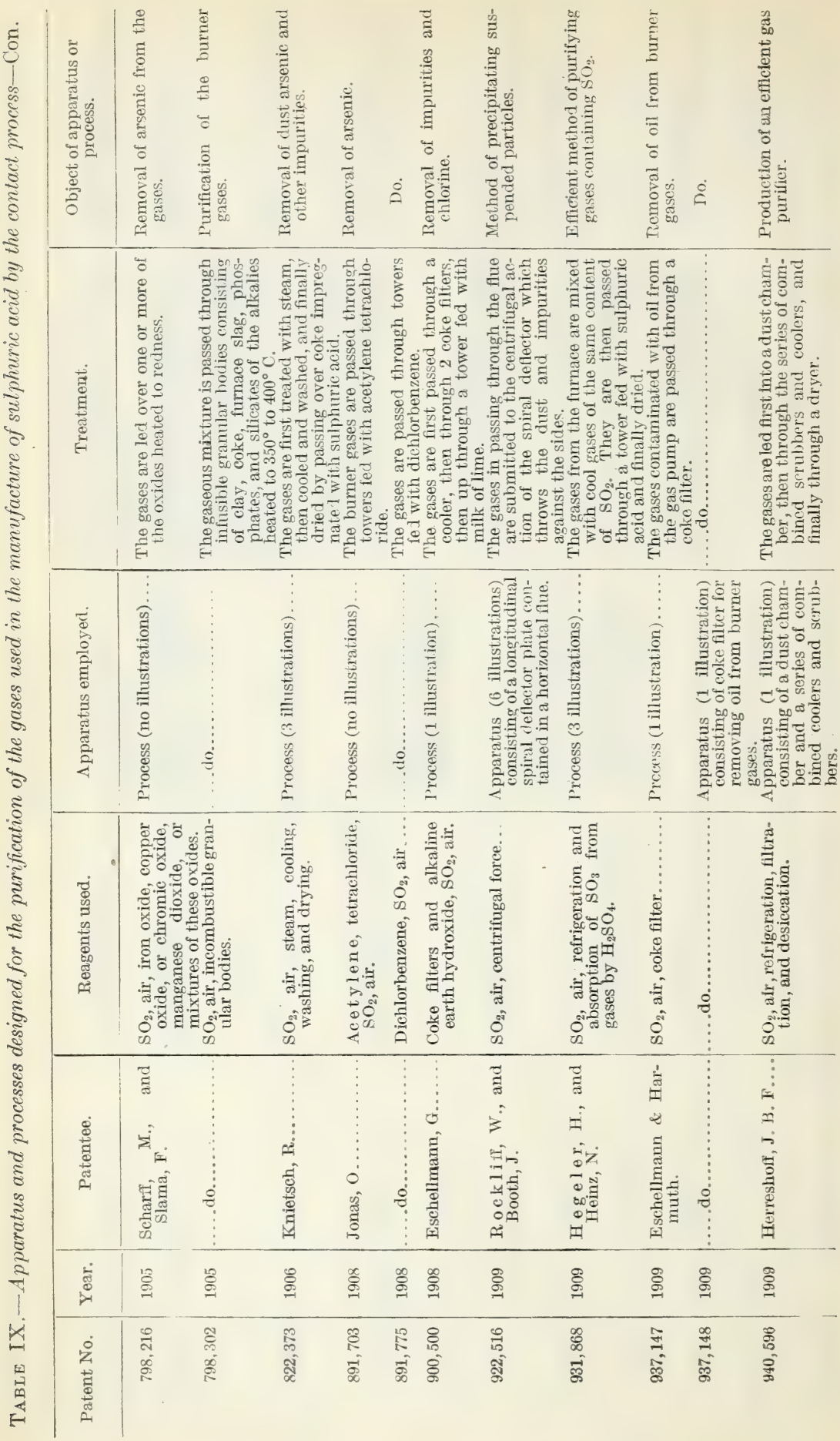




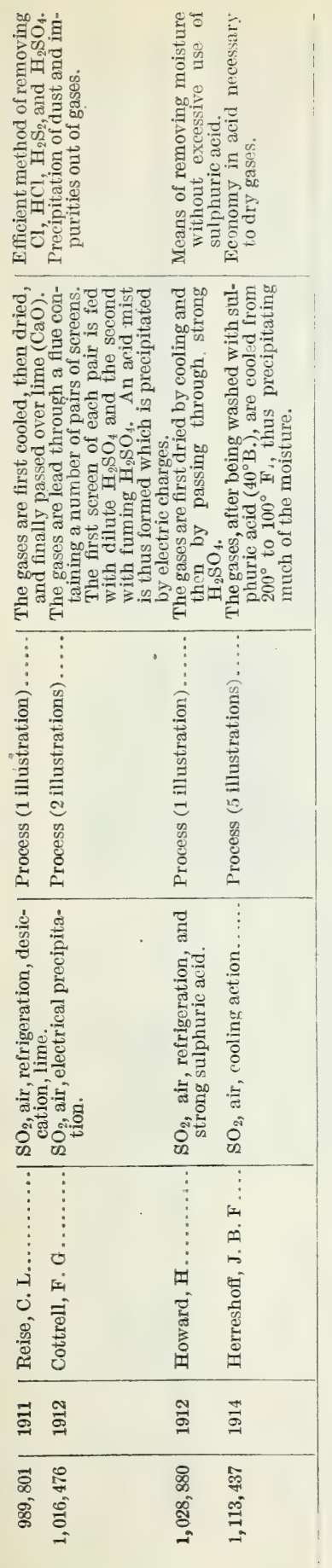


BULLETIN 283, U. S. DEPARTMENT OF AGRICULTURE.

\begin{tabular}{|c|c|c|c|c|c|c|c|c|c|}
\hline 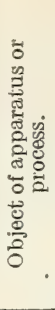 & 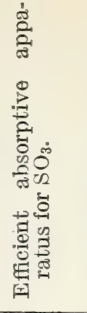 & 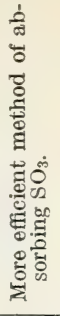 & 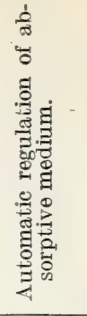 & $\dot{\AA}$ & 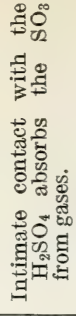 & 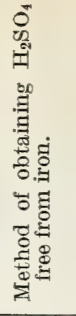 & 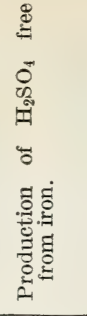 & 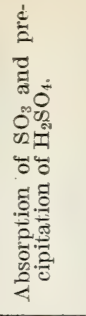 & 竞 \\
\hline 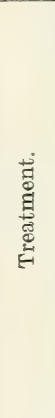 & 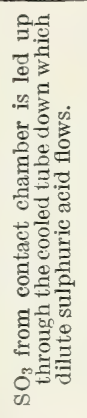 & \multicolumn{3}{|c|}{ 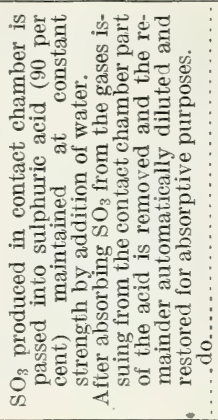 } & 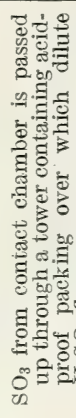 & 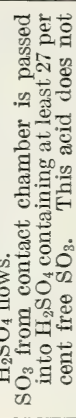 & 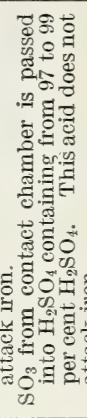 & 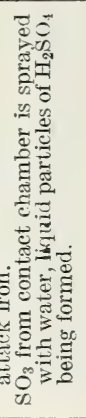 & 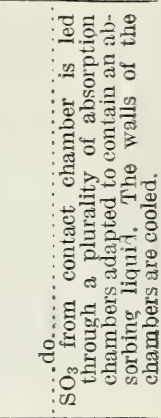 \\
\hline 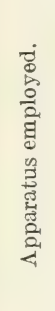 & \multicolumn{2}{|c|}{ 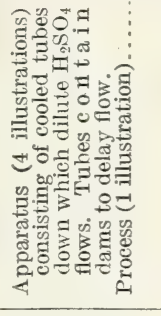 } & ¿ & \multicolumn{2}{|c|}{ 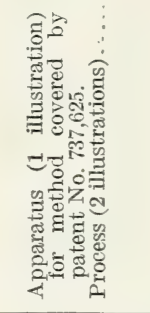 } & 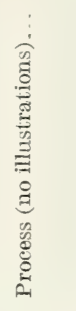 & 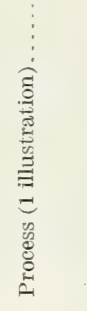 & \multicolumn{2}{|c|}{ 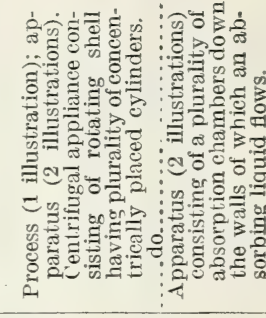 } \\
\hline 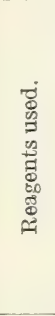 & 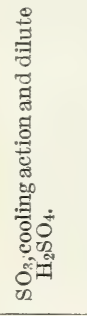 & 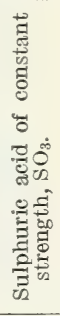 & 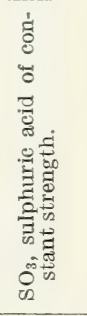 & 0 & 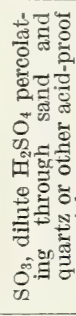 & 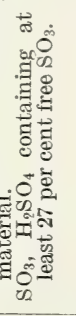 & 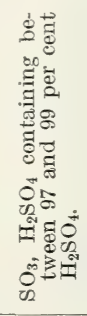 & 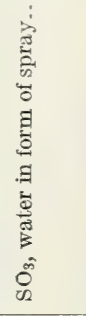 & 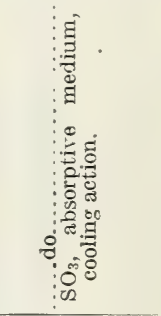 \\
\hline 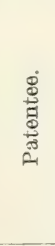 & 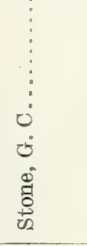 & 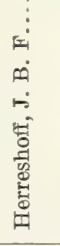 & 8 & व & 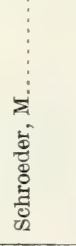 & 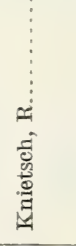 & ஜ̊ & 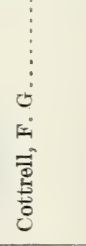 & 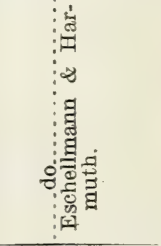 \\
\hline 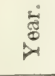 & 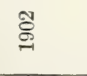 & 怘 & 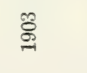 & . & : & 总 & $\underset{్}{\&}$ & హ్ & స్త్తిథ్తి \\
\hline 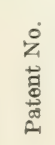 & $\begin{array}{l}80 \\
0 \\
80\end{array}$ & $\begin{array}{l}\vec{\infty} \\
\stackrel{5}{~} \\
\vec{N}\end{array}$ & 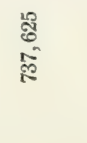 & 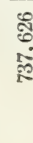 & 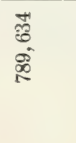 & $\begin{array}{l}\infty \\
\text { न } \\
\hat{8} \\
\hat{\infty}\end{array}$ & $\begin{array}{l}\infty \\
\vec{\sigma} \\
0 \\
\infty\end{array}$ & $\begin{array}{l}\infty \\
\infty \\
\infty \\
0 \\
\infty\end{array}$ & 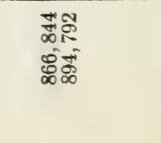 \\
\hline
\end{tabular}




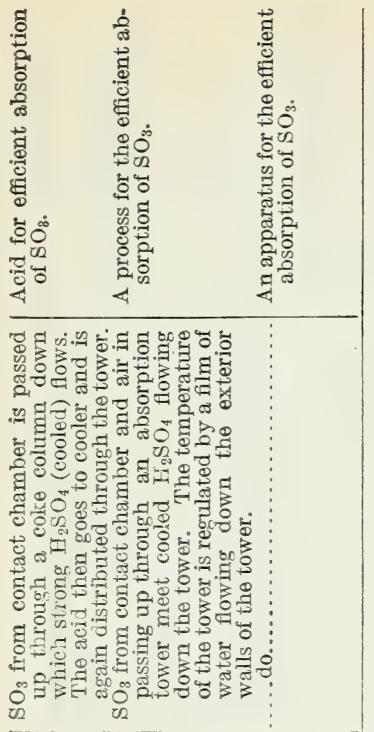

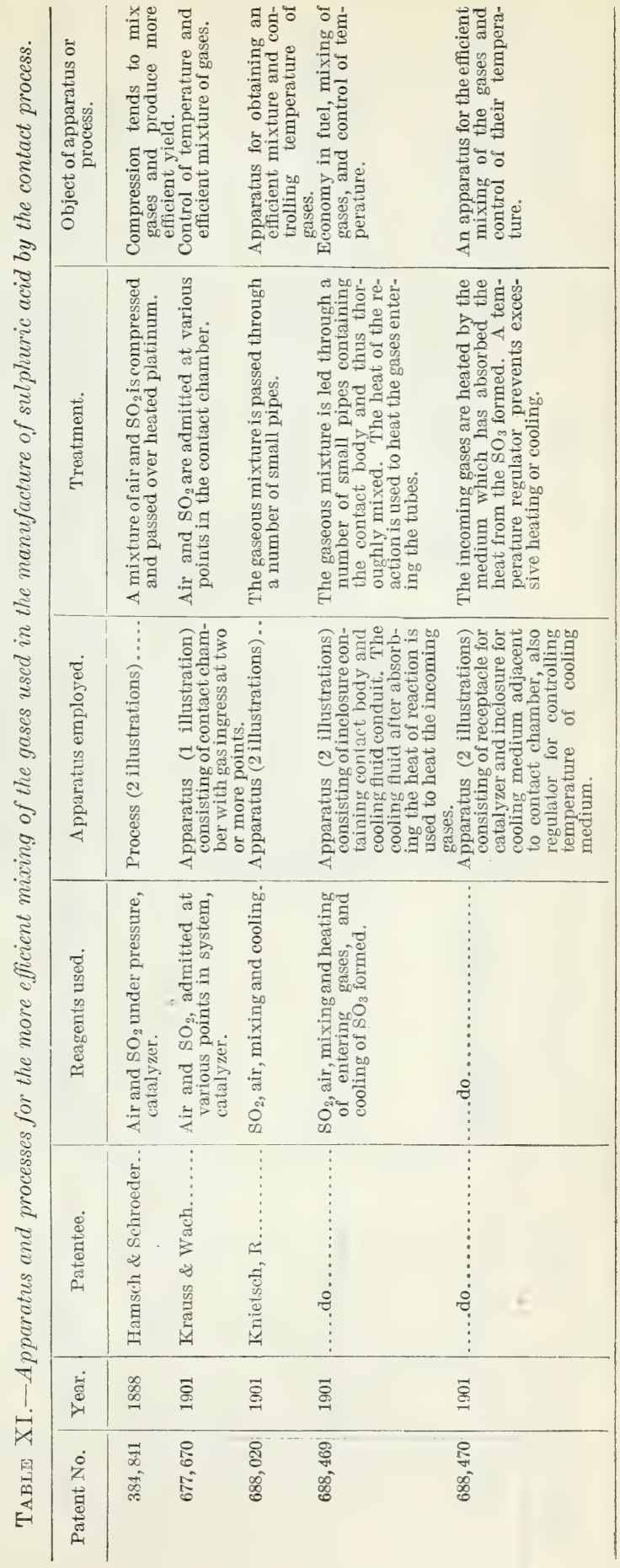


BULLETIN 283, U. S. DEPARTMENT OF AGRICULTURE.

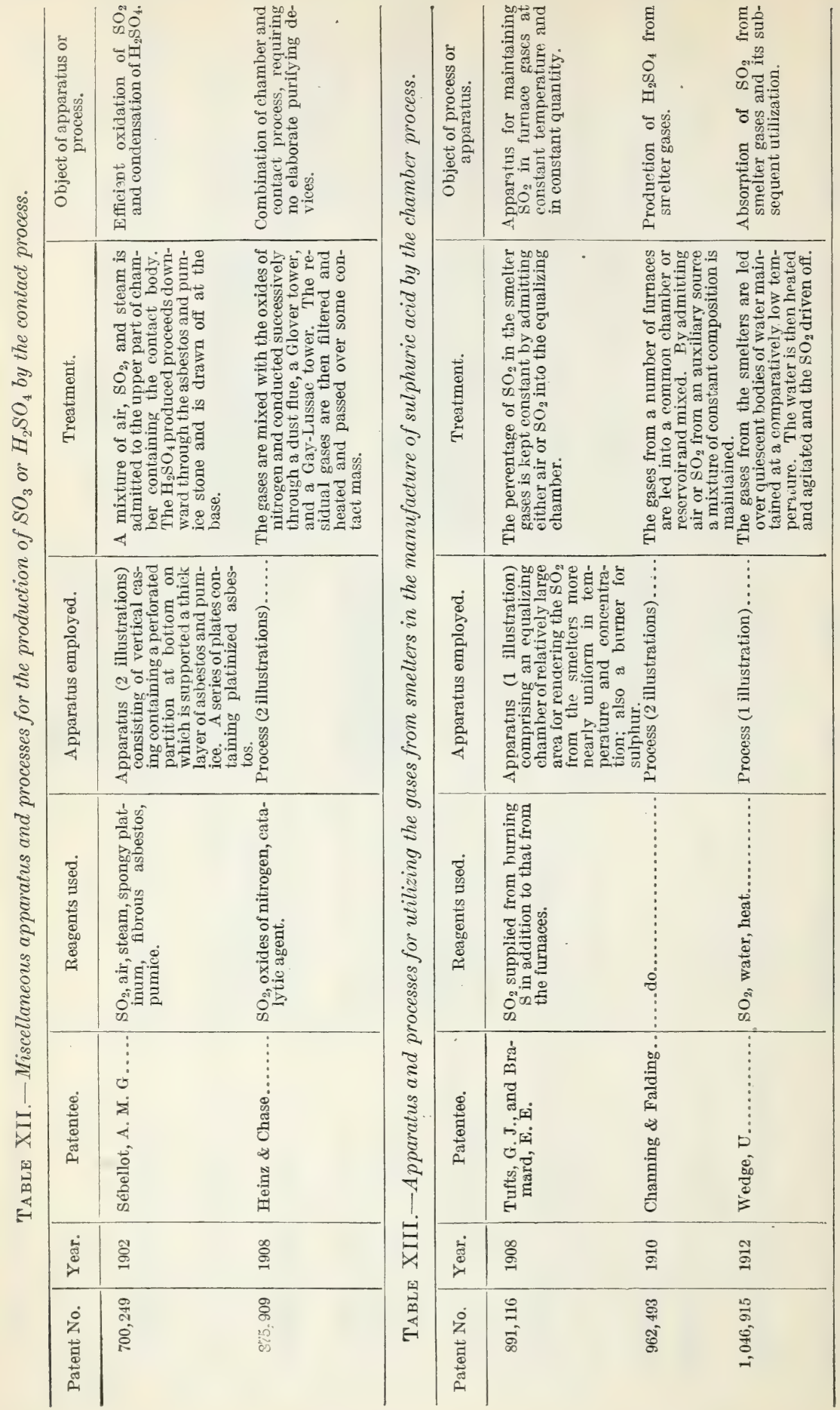


PRODUCTION OF SULPHURIC ACID.

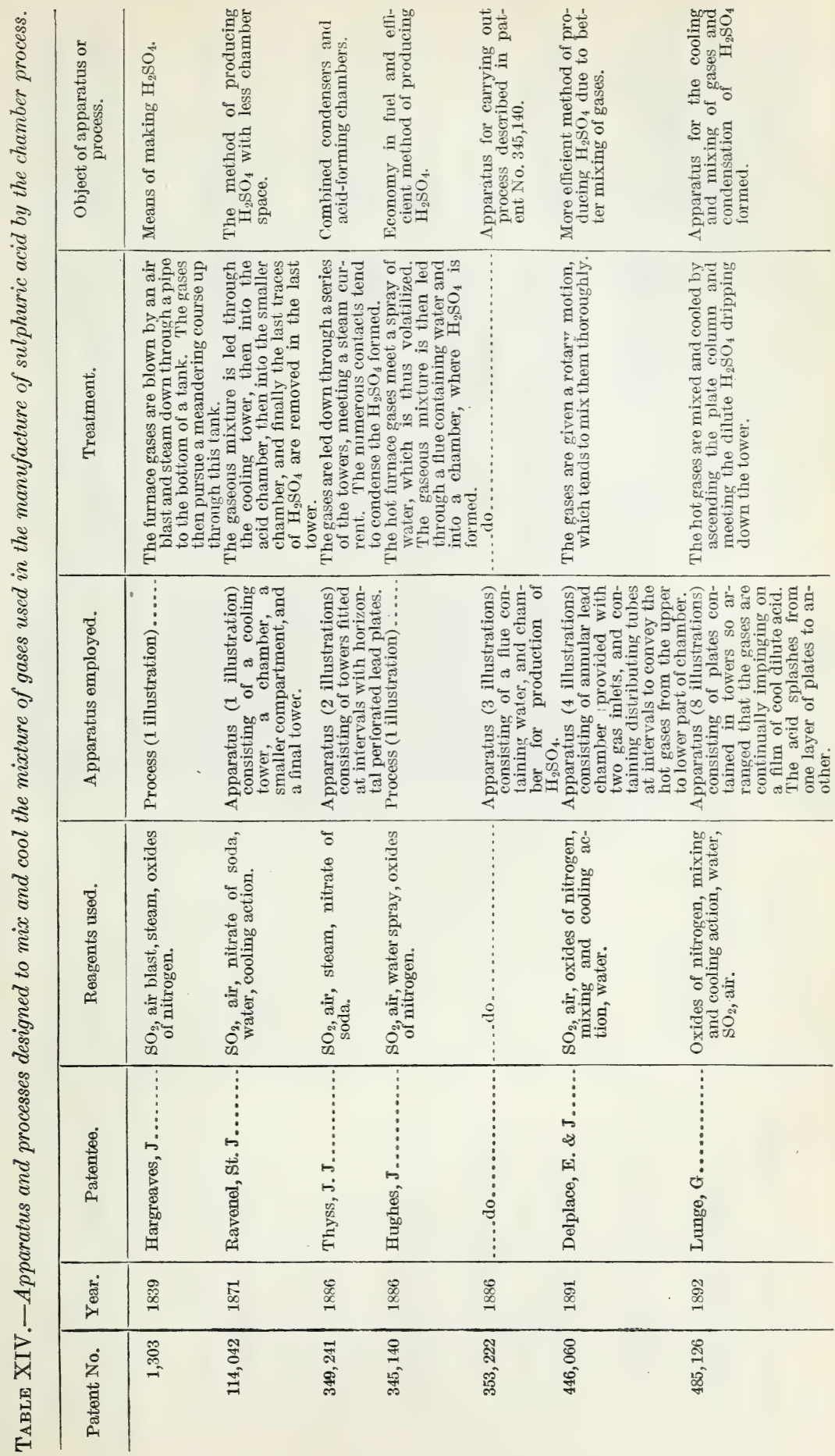


BULLETIN 283, U. S. DEPARTMENT OF AGRICULTURE.

\begin{tabular}{|c|c|c|c|c|c|c|}
\hline 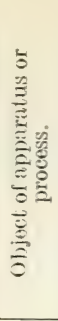 & 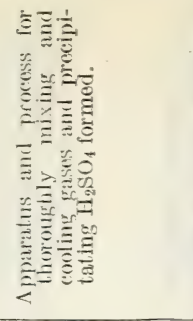 & 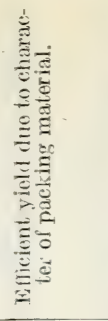 & 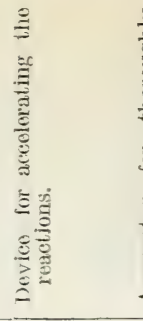 & 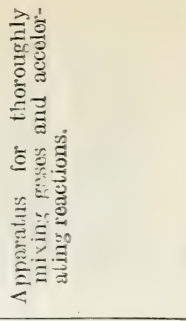 & 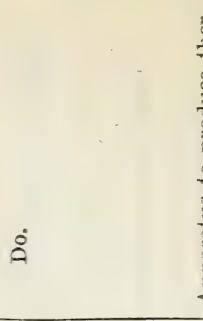 & 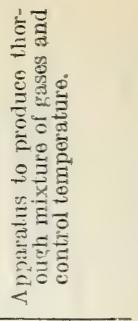 \\
\hline 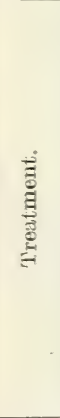 & 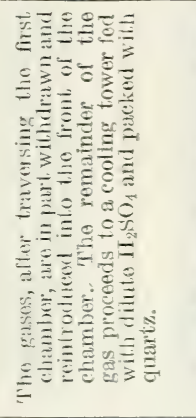 & 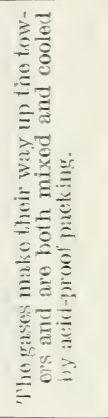 & 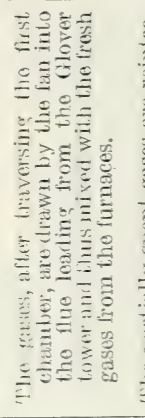 & 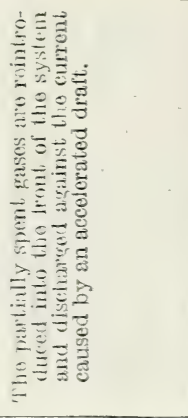 & 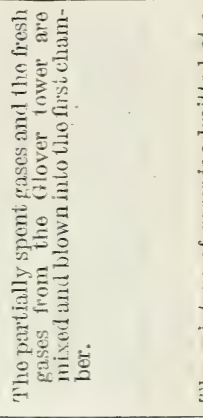 & 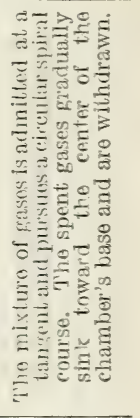 \\
\hline 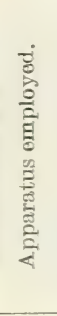 & 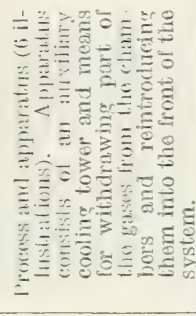 & 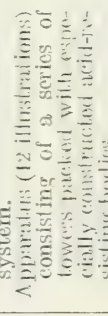 & 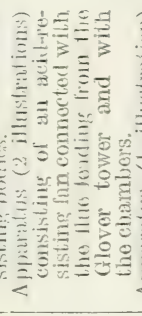 & 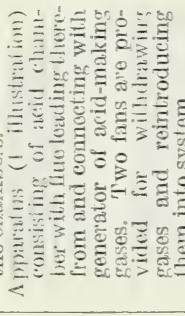 & 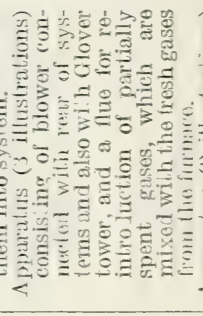 & 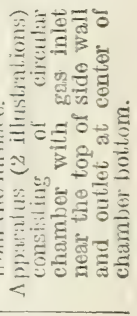 \\
\hline 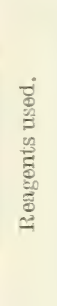 & 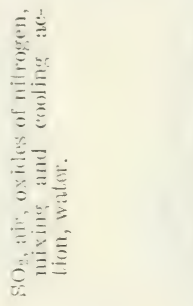 & $\doteq$ & & & $\cong$ & 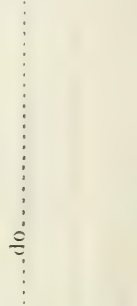 \\
\hline
\end{tabular}




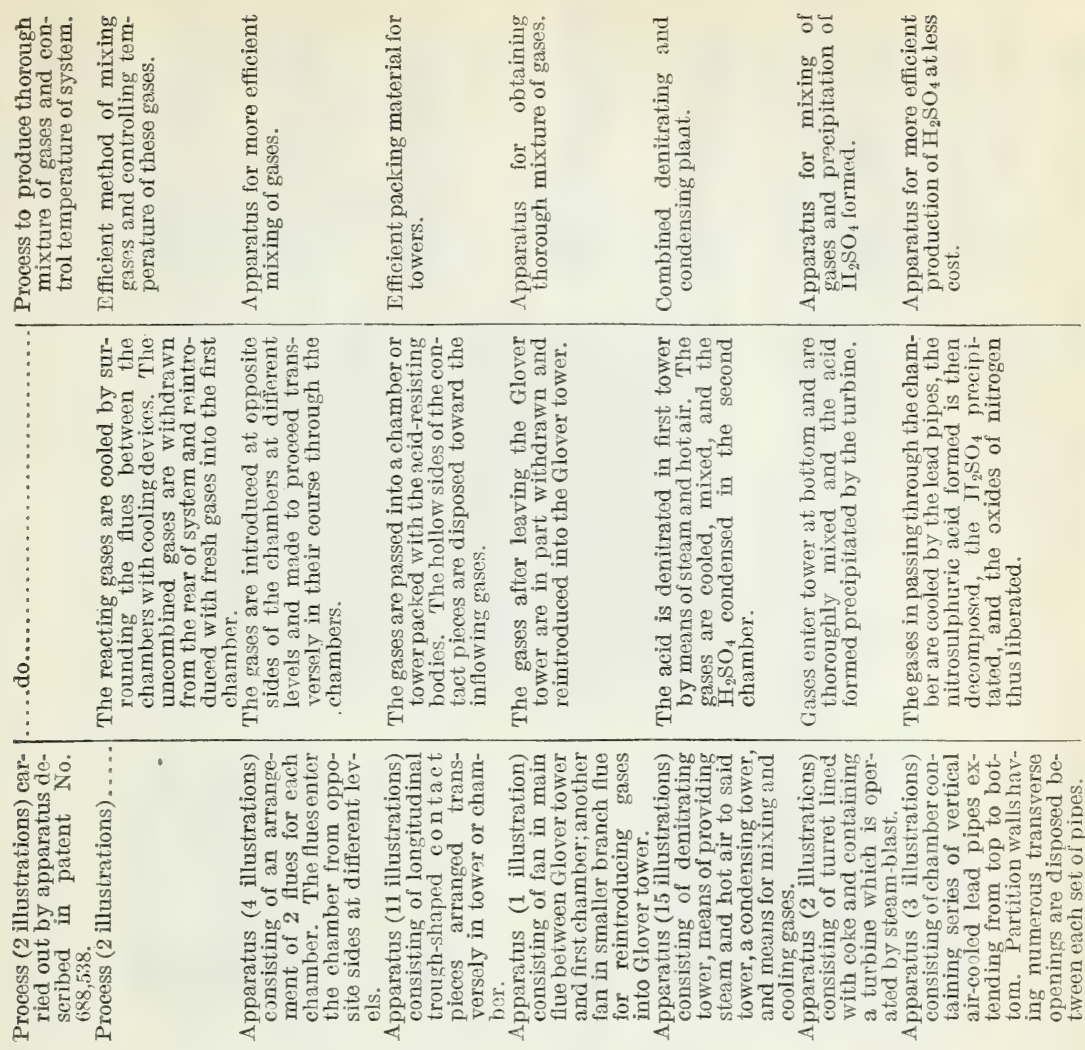

$\div$

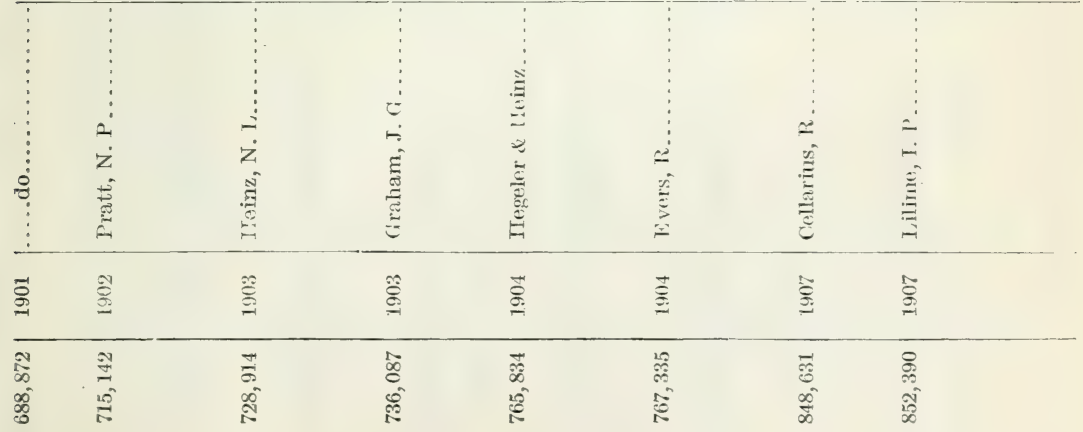


BULLETIN 283, U. S. DEPARTMENT OF AGRICULTURE.

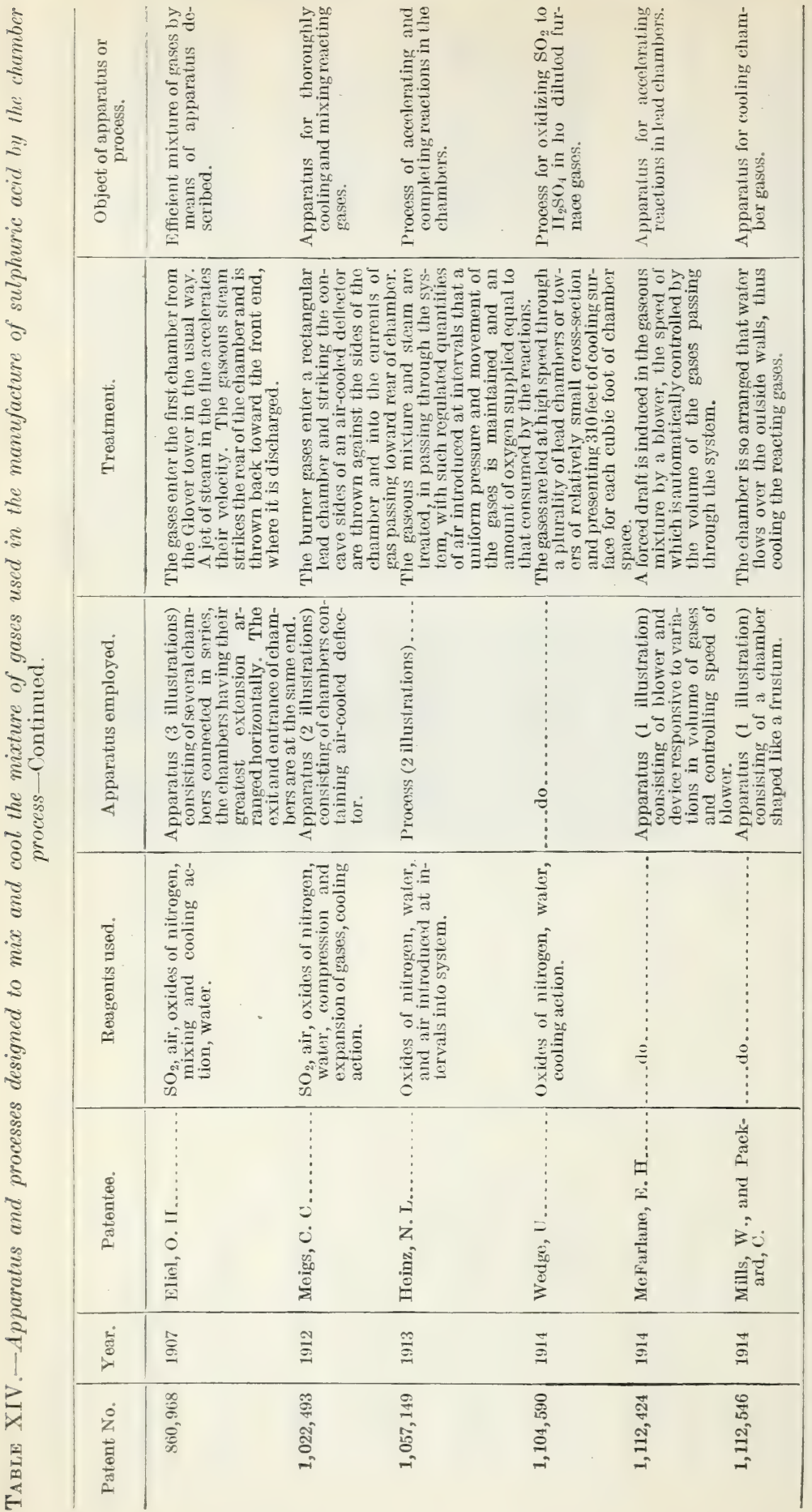




\begin{tabular}{|c|c|c|c|c|c|c|}
\hline \multicolumn{2}{|r|}{ 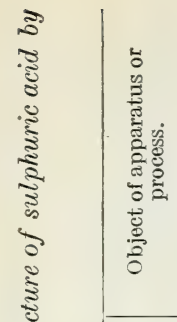 } & 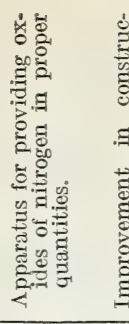 & 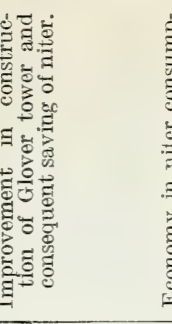 & 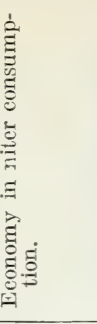 & 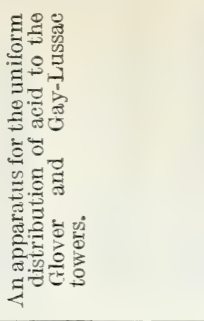 & 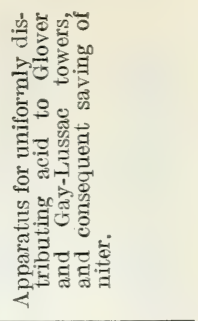 \\
\hline 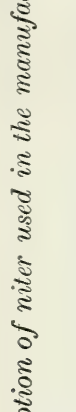 & 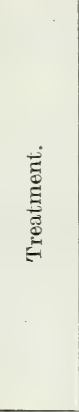 & 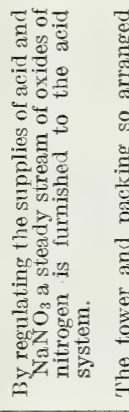 & 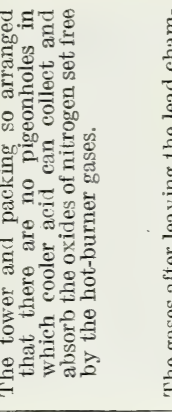 & 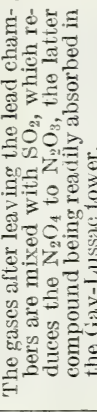 & 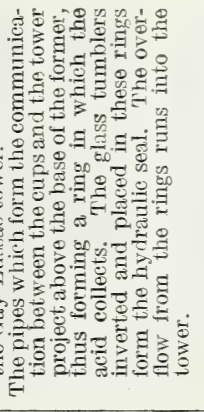 & 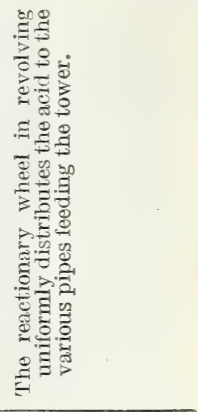 \\
\hline 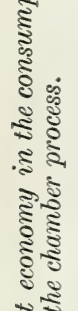 & 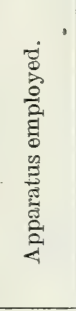 & 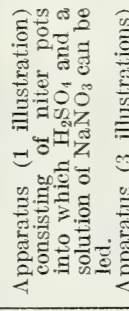 & 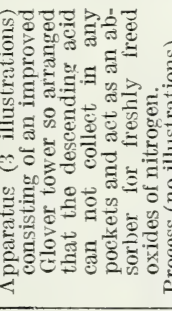 & 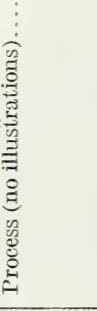 & 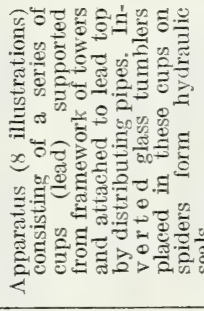 & 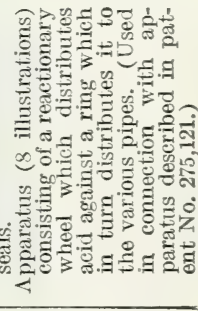 \\
\hline 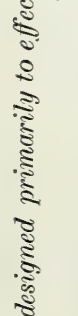 & 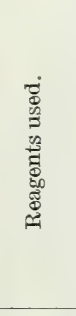 & 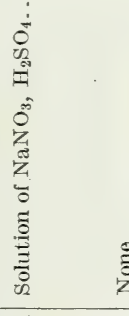 & 官 & 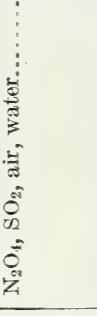 & $\begin{array}{r}\vdots \\
\vdots \\
\\
z \\
\end{array}$ & 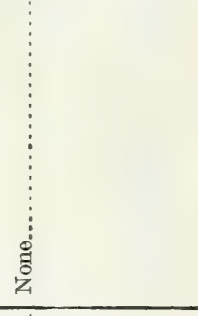 \\
\hline 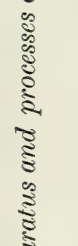 & 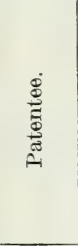 & $\begin{array}{c}\vdots \\
\dot{2} \\
\dot{m} \\
\dot{0} \\
\frac{0}{\pi}\end{array}$ & 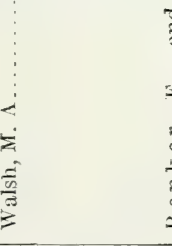 & 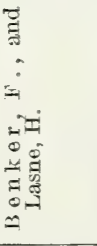 & 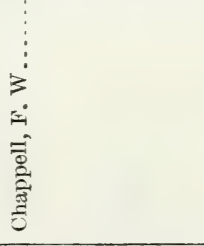 & ơ \\
\hline 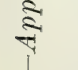 & 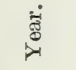 & $\begin{array}{l}\vec{x} \\
\stackrel{0}{-}\end{array}$ & 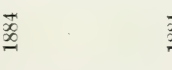 & $\begin{array}{l}\vec{x} \\
\stackrel{x}{\sim}\end{array}$ & $\begin{array}{l}\hat{x} \\
\underset{x}{x} \\
\sim\end{array}$ & $\begin{array}{l}\infty \\
\infty \\
\stackrel{\infty}{\sim}\end{array}$ \\
\hline 国 & 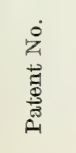 & 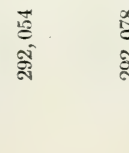 & 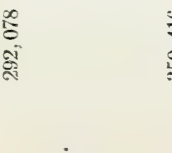 & 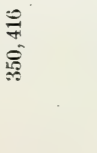 & 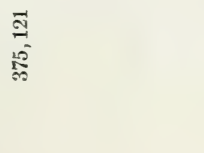 & 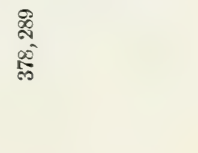 \\
\hline
\end{tabular}




\begin{tabular}{|c|c|c|c|c|c|c|c|}
\hline 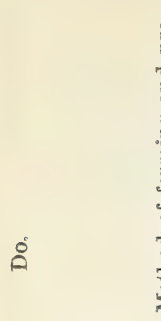 & 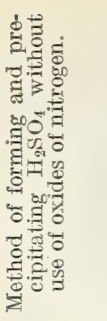 & 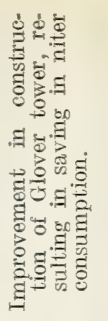 & 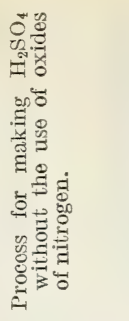 & 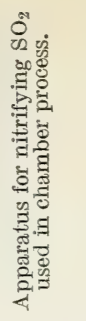 & 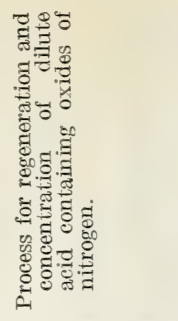 & 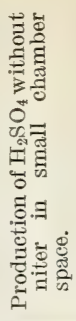 & 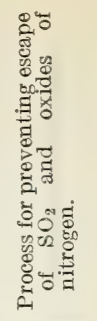 \\
\hline 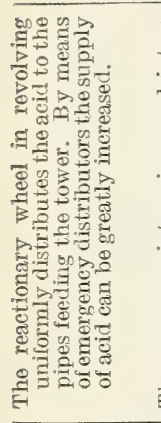 & 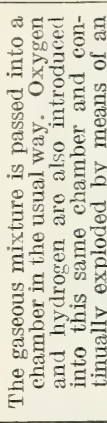 & 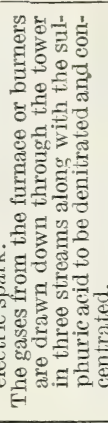 & 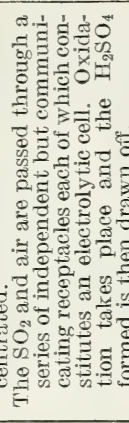 & 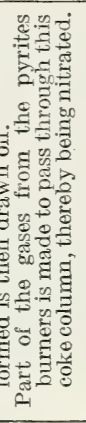 & 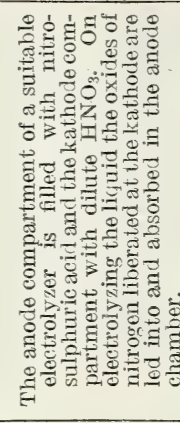 & 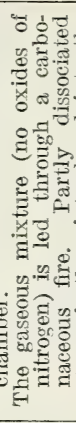 & 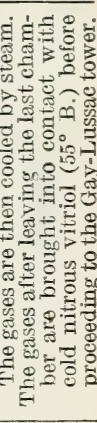 \\
\hline 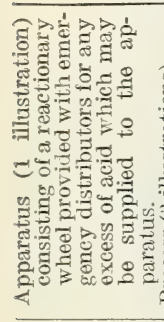 & 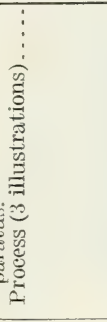 & 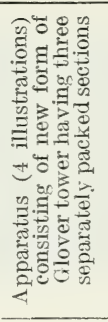 & 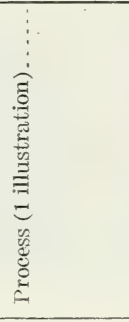 & 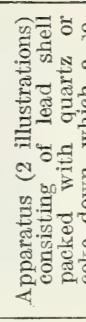 & 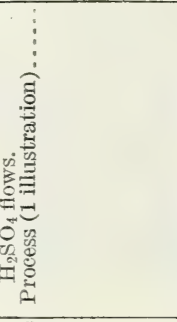 & 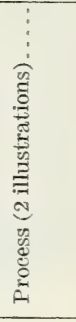 & $\begin{array}{c}0 \\
\vdots \\
\vdots\end{array}$ \\
\hline छี & 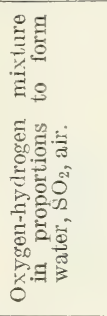 & 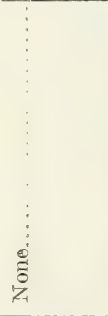 & 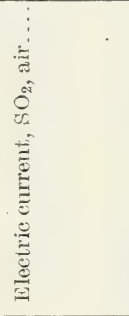 & 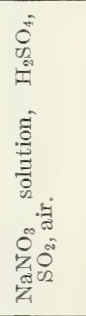 & 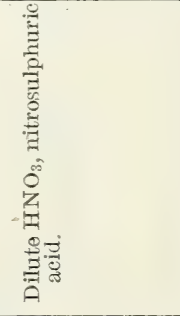 & 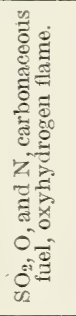 & 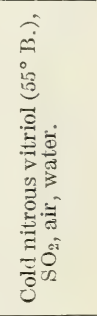 \\
\hline 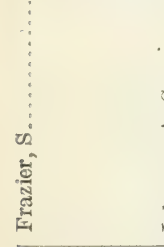 & 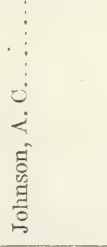 & 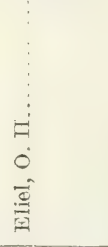 & 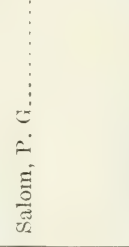 & $\begin{array}{l}\vec{H} \\
\overrightarrow{0} \\
\stackrel{6}{0}\end{array}$ & 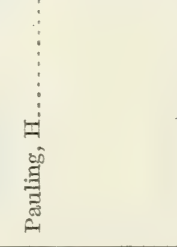 & 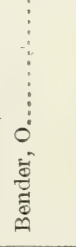 & 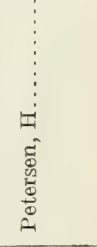 \\
\hline$\infty$ & $\stackrel{8}{\mathscr{G}}$ & 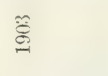 & 莕 & 总 & $\stackrel{\infty}{\stackrel{\circ}{ٌ ~}}$ & 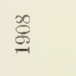 & $\stackrel{\infty}{\stackrel{2}{2}}$ \\
\hline 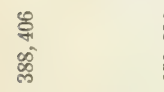 & $\begin{array}{l}\mathscr{N} \\
\text { న్ } \\
\text { ధి }\end{array}$ & సิ & 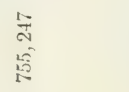 & $\begin{array}{l}\text { \& } \\
\infty \\
0 \\
\infty \\
\infty\end{array}$ & $\begin{array}{l}\text { \& } \\
\infty \\
\infty \\
\infty\end{array}$ & $\begin{array}{l}\infty \\
0 \\
0 \\
\& \\
\&\end{array}$ & $\begin{array}{l}\text { ज्ञ } \\
\text { है }\end{array}$ \\
\hline
\end{tabular}




\begin{tabular}{|c|c|c|}
\hline 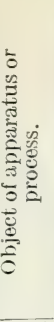 & 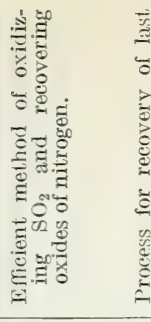 & 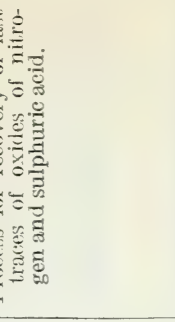 \\
\hline 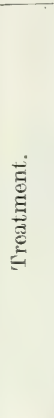 & 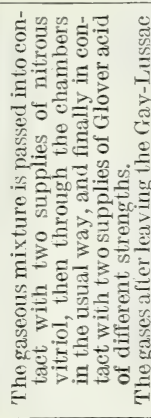 & 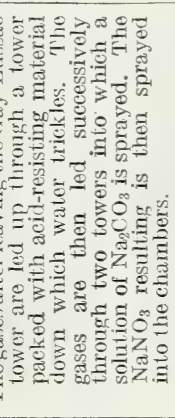 \\
\hline 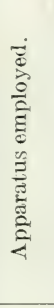 & 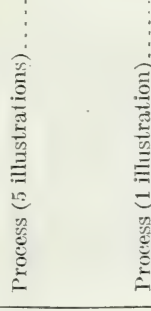 & \\
\hline 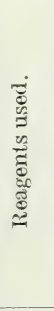 & 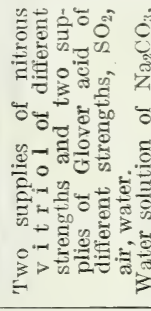 & 弯 \\
\hline 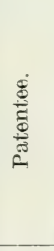 & 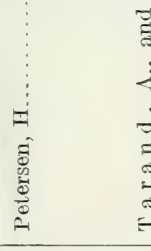 & 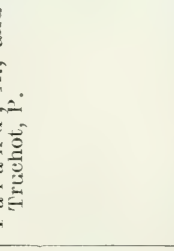 \\
\hline 局 & $\stackrel{\$}{. ~}$ & 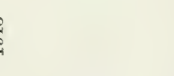 \\
\hline $\begin{array}{l}\dot{8} \\
\dot{z} \\
\vec{E} \\
\frac{\vec{E}}{\tilde{E}} \\
\tilde{c}\end{array}$ & 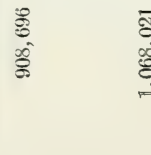 & \\
\hline
\end{tabular}




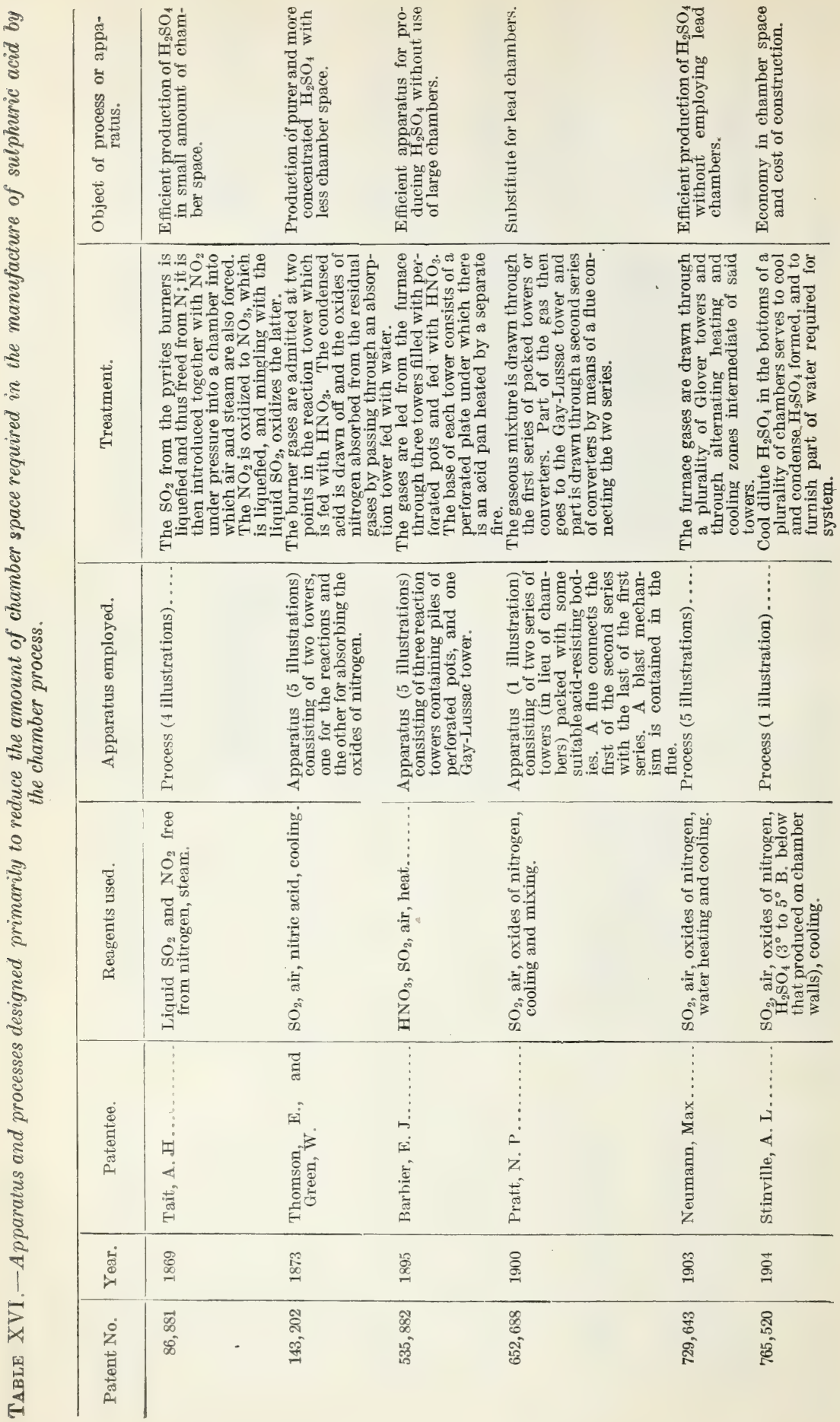




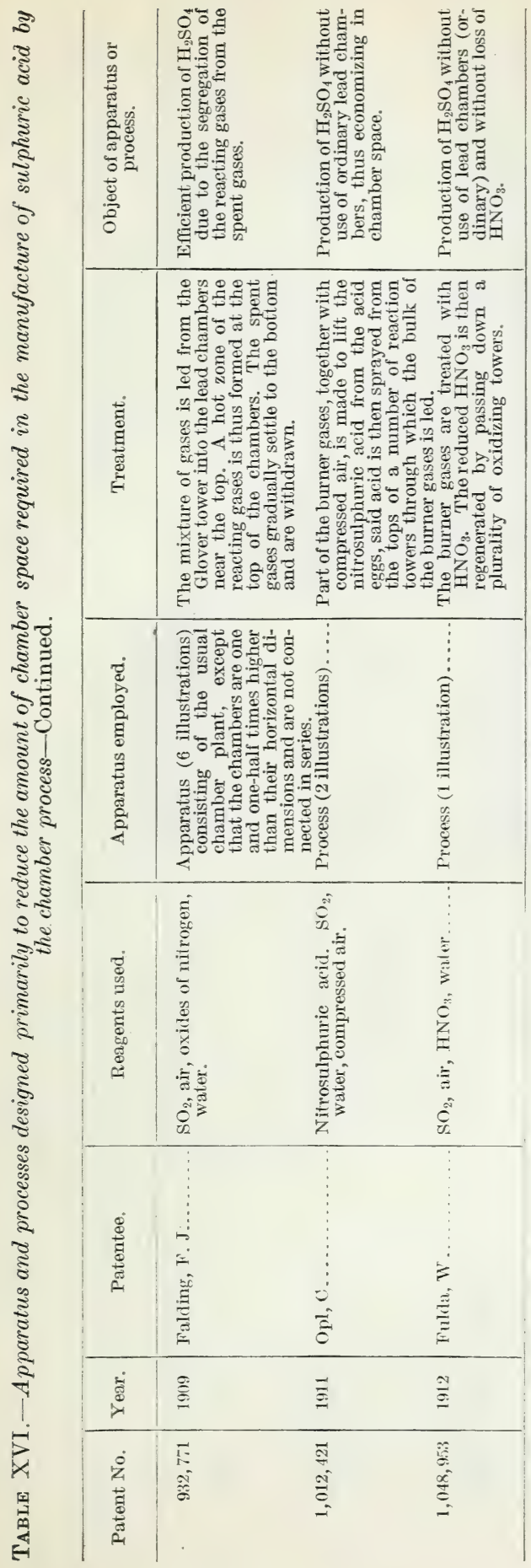




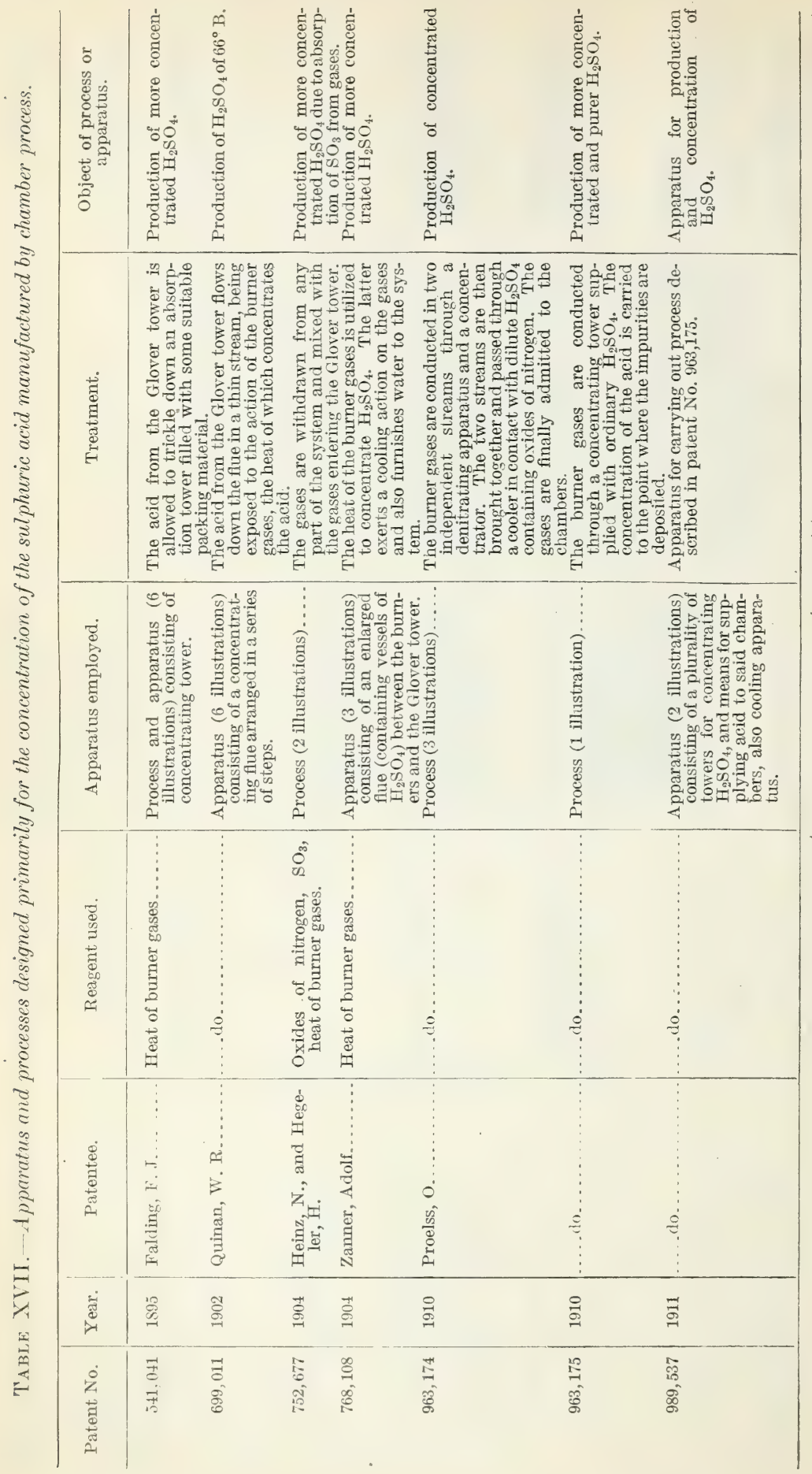


PRODUCTION OF SULPHURIC ACID.

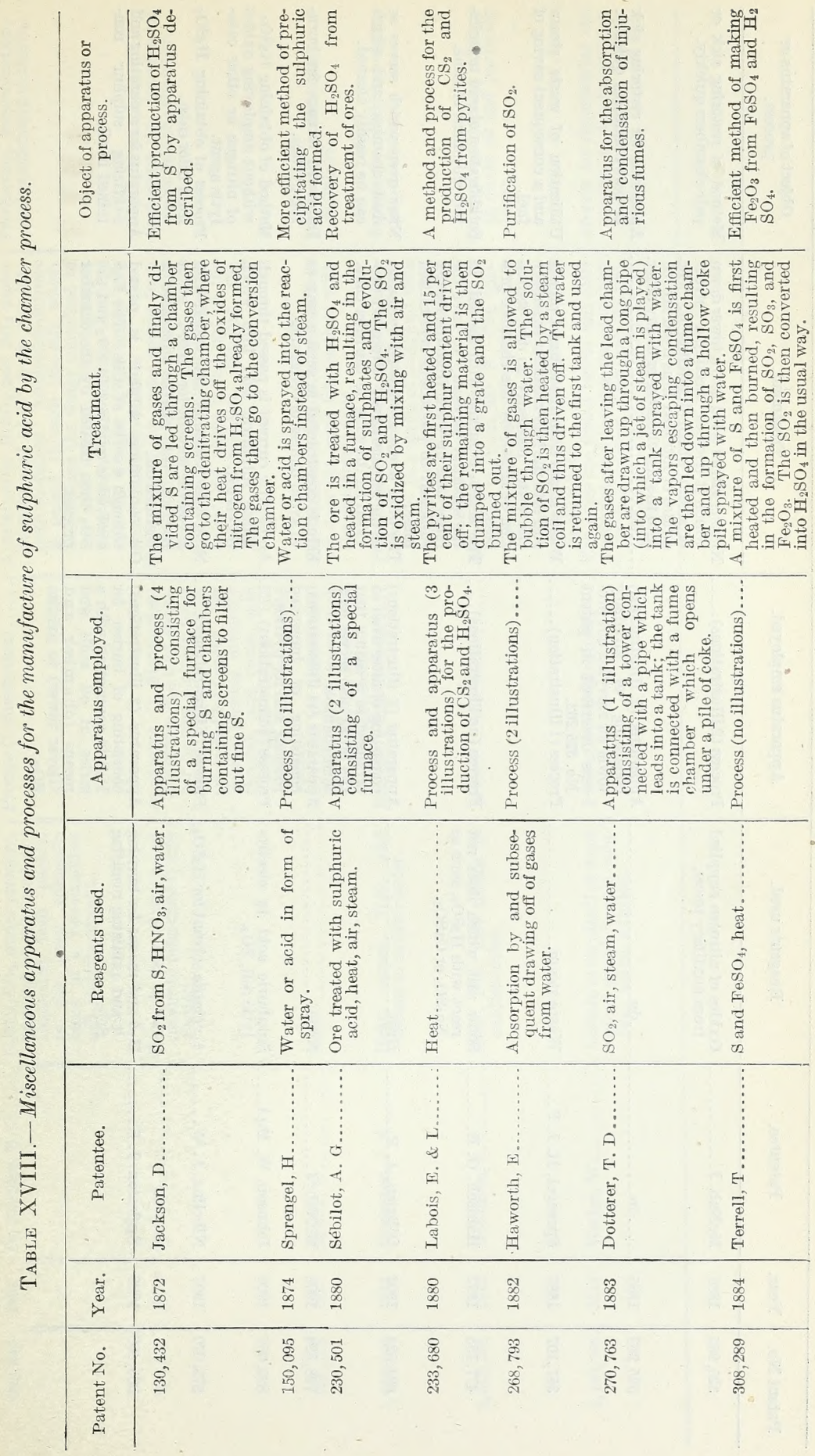




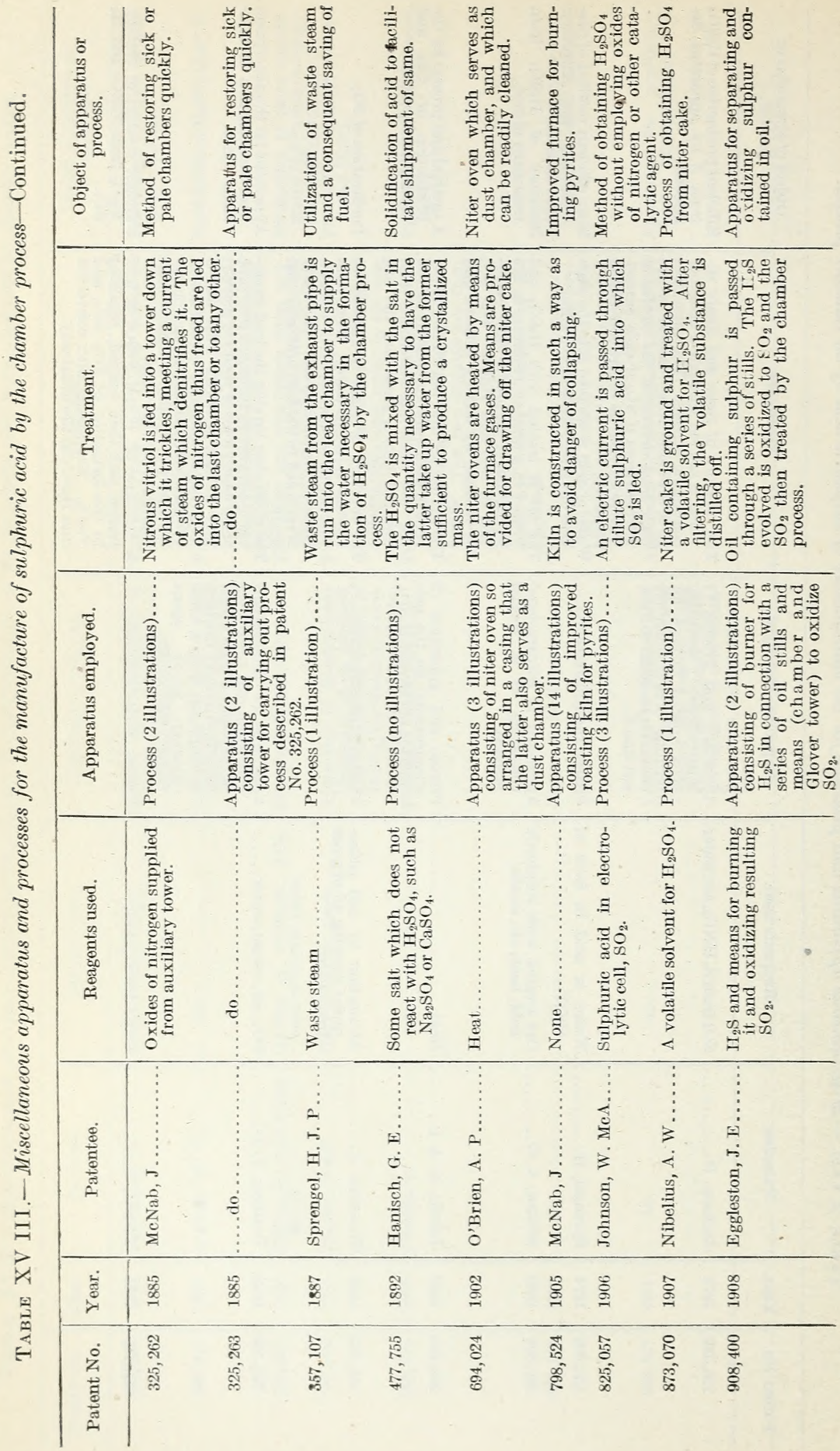




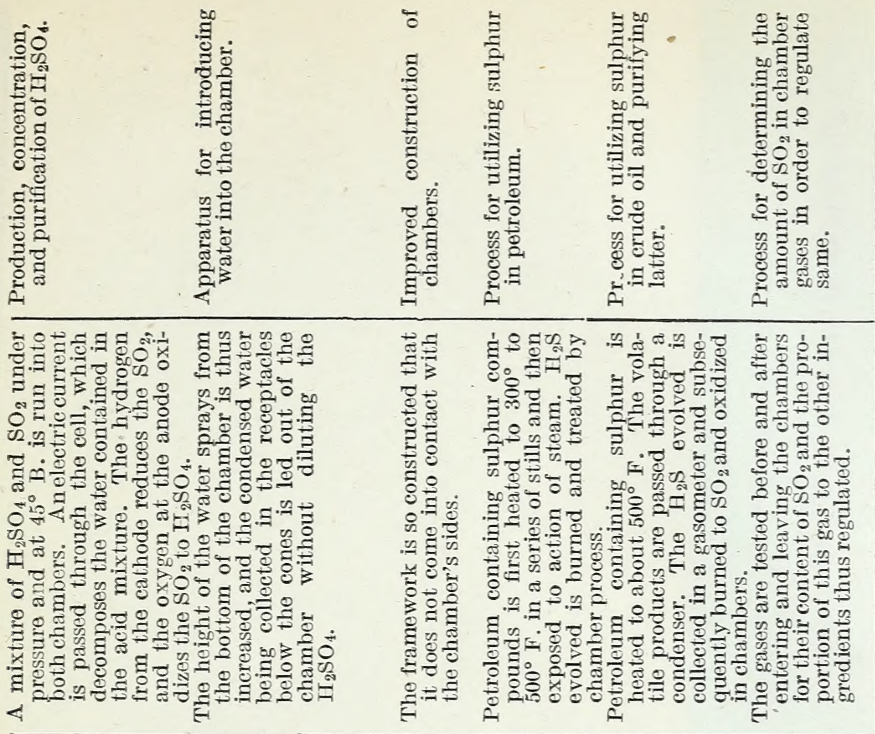

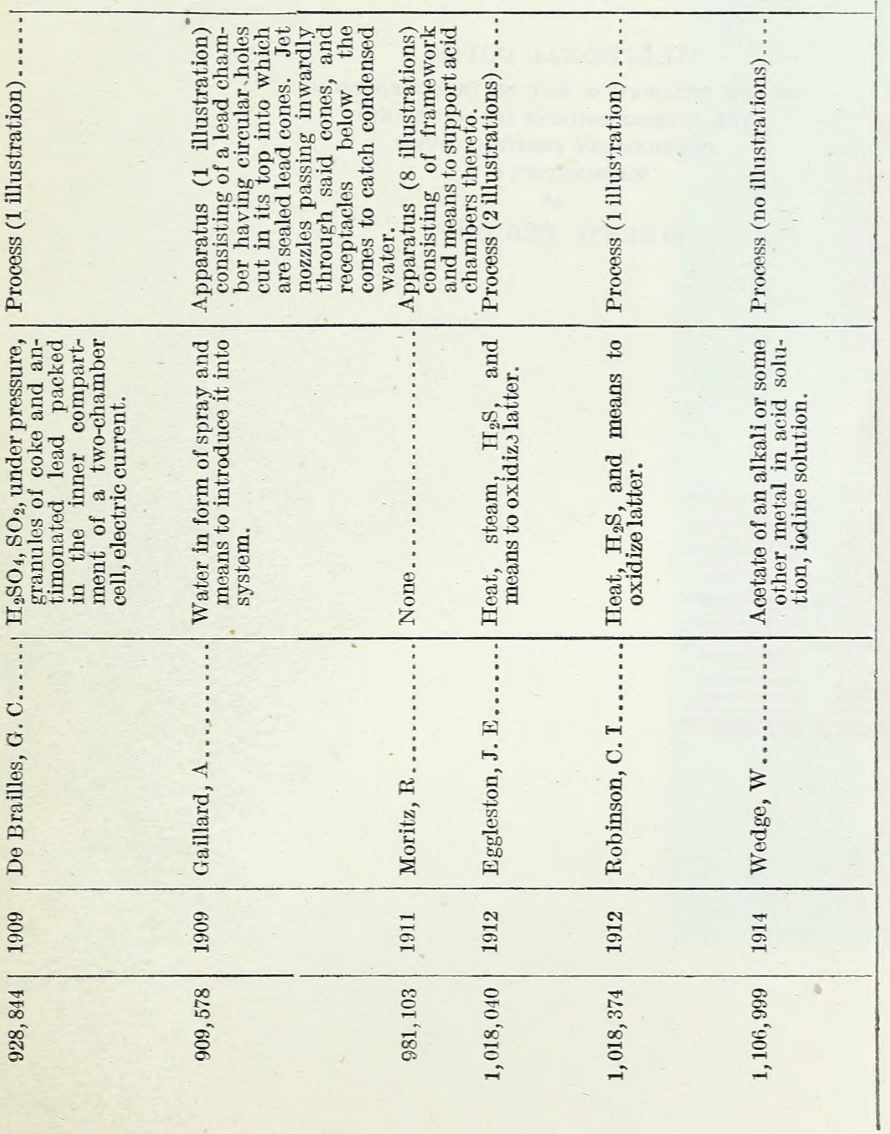


ADDITIONAL COPIES

OF THIS PUBLICATION MAY BE PROCURED FROM THE SUPERINTENDENT OF DOCUMIENTS GOVERNMENT PRINTING OFFICE

WASHINGTON, D. C.

AT

.10 CENTS PER COPY 